\title{
Dimethylimidazolium-Functionalized Polybenzimidazole and Its Organic-Inorganic Hybrid Membranes for Anion Exchange Membrane Fuel Cells
}

\author{
Li-Cheng Jheng ${ }^{1}{ }^{(\mathbb{D}}$, Cheng-Wei Cheng ${ }^{2}$, Ko-Shan Ho ${ }^{1}$, Steve Lien-Chung Hsu ${ }^{2} * \mathbb{D}$, Chung-Yen Hsu ${ }^{1}$, \\ Bi-Yun Lin $^{3}$ and Tsung-Han Ho ${ }^{1, *}$
}

1 Department of Chemical and Materials Engineering, National Kaohsiung University of Science and Technology, Kaohsiung 80778, Taiwan; lcjheng@nkust.edu.tw (L.-C.J.); hks@nkust.edu.tw (K.-S.H.); j841216@gmail.com (C.-Y.H.)

2 Department of Materials Science and Engineering, National Cheng Kung University, Tainan 70101, Taiwan; kevin850427@gmail.com

3 Instrument Center of National Cheng Kung University, Tainan 70101, Taiwan; z7710011@email.ncku.edu.tw

* Correspondence: lchsu@mail.ncku.edu.tw (S.L.-C.H.); thho@nkust.edu.tw (T.-H.H.)

Citation: Jheng, L.-C.; Cheng, C.-W.; Ho, K.-S.; Hsu, S.L.-C.; Hsu, C.-Y.; Lin, B.-Y.; Ho, T.-H.

Dimethylimidazolium-

Functionalized Polybenzimidazole and Its Organic-Inorganic Hybrid

Membranes for Anion Exchange Membrane Fuel Cells. Polymers 2021, 13, 2864. https://doi.org/10.3390/ polym13172864

Academic Editors: Mrinmay Mandal and Chengji Zhao

Received: 31 July 2021

Accepted: 22 August 2021

Published: 26 August 2021

Publisher's Note: MDPI stays neutral with regard to jurisdictional claims in published maps and institutional affiliations.

Copyright: (c) 2021 by the authors. Licensee MDPI, Basel, Switzerland. This article is an open access article distributed under the terms and conditions of the Creative Commons Attribution (CC BY) license (https:/ / creativecommons.org/licenses/by/ $4.0 /)$.
Abstract: A quaternized polybenzimidazole (PBI) membrane was synthesized by grafting a dimethylimidazolium end-capped side chain onto PBI. The organic-inorganic hybrid membrane of the quaternized PBI was prepared via a silane-induced crosslinking process with triethoxysilylpropyl dimethylimidazolium chloride. The chemical structure and membrane morphology were characterized using NMR, FTIR, TGA, SEM, EDX, AFM, SAXS, and XPS techniques. Compared with the pristine membrane of dimethylimidazolium-functionalized PBI, its hybrid membrane exhibited a lower swelling ratio, higher mechanical strength, and better oxidative stability. However, the morphology of hydrophilic/hydrophobic phase separation, which facilitates the ion transport along hydrophilic channels, only successfully developed in the pristine membrane. As a result, the hydroxide conductivity of the pristine membrane $\left(5.02 \times 10^{-2} \mathrm{~S} \mathrm{~cm}^{-1}\right.$ at $\left.80^{\circ} \mathrm{C}\right)$ was measured higher than that of the hybrid membrane $\left(2.22 \times 10^{-2} \mathrm{~S} \mathrm{~cm}^{-1}\right.$ at $\left.80^{\circ} \mathrm{C}\right)$. The hydroxide conductivity and tensile results suggested that both membranes had good alkaline stability in $2 \mathrm{M} \mathrm{KOH}$ solution at $80{ }^{\circ} \mathrm{C}$. Furthermore, the maximum power densities of the pristine and hybrid membranes of dimethylimidazolium-functionalized PBI reached $241 \mathrm{~mW} \mathrm{~cm}^{-2}$ and $152 \mathrm{~mW} \mathrm{~cm}{ }^{-2}$ at $60{ }^{\circ} \mathrm{C}$, respectively. The fuel cell performance result demonstrates that these two membranes are promising as AEMs for fuel cell applications.

Keywords: polybenzimidazole; anion exchange membrane; fuel cells; dimethylimidazolium; organicinorganic hybrid membrane

\section{Introduction}

Polymer electrolyte membrane fuel cells are one type of fuel cell suitable for portable and transportation applications, which feature quick start-up, low operation temperature, low cost, high efficiency, and so on [1,2]. Depending on the polymer electrolyte membrane, this type of fuel cell can be further divided into proton exchange membrane fuel cell (PEMFC) [3,4] and anion exchange membrane fuel cell (AEMFC) [5,6]. AEMFC has been attracted considerable attention in the recent decade due to several advantages over PEMFC, including (1) faster oxygen reduction reaction (ORR) under the basic condition that allows the catalyst at the cathode to employ platinum-free metal or low-platinum catalysts [7-9], (2) negligible fuel crossover owing to the hydroxide transport direction opposite to the direction of liquid fuel's crossover (e.g., methanol) [10,11], as well as (3) minimized corrosion problems in alkaline environments [2,12].

Although AEMFC is one of the most promising platinum-free fuel cells for power conversion applications, its core component, anion exchange membrane (AEM), still faces 
several challenges, such as insufficient hydroxide conductivity, poor dimensional stability, and inadequate alkaline stability [13]. Generally, there is a trade-off relationship between the ionic conductivity and dimensional stability of an AEM [14]. For most AEMs, high IEC leads to an increased hydroxide conductivity but impaired dimensional stability due to excessive water-uptake [15]. Additionally, most commonly used cationic groups (e.g., quaternary ammonium, imidazolium, benzimidazolium, sulfonium) for AEMs are unstable and susceptible to degrade via nucleophilic displacement or Hofmann elimination under high $\mathrm{pH}$ conditions especially at temperatures above $60^{\circ} \mathrm{C}[16,17]$. Furthermore, main chain type AEMs constituted by polymers bearing cationic groups in the main chain may accelerate the alkaline degradation of cationic groups because of the electron-withdrawing effect of the benzene ring particularly for polymers containing aryl ether moieties [18]. To solve these addressed problems simultaneously, fabricating hydrophilic ion transport channels in the AEMs through the ionic clustering formation and the hydrophilic/hydrophobic micro-phase separations has been suggested as a feasible strategy [13].

Preparing side chain type AEMs (or called comb-shaped polymer based AEMs), which is composed of flexible long side chains with hydrophilic cationic groups covalently grafted onto the polymer backbone, is one of efficient ways to develop hydrophilic/hydrophobic micro-phase separations due to the dissimilarity between the side chain and polymer backbone [7]. Recently, a variety of polymer backbones have been investigated for developing side chain type AEMs with high performance, such as polyphenylene oxide (PPO) [19,20], polyarylene ether sulfone (PAES) [21,22], polyether ether ketone (PEEK) [23], polybenzimidazole (PBI) [24-26], polynorbornene [27,28], polystyrene-based copolymer [29,30]. However, aryl ether-containing based AEMs might suffer from alkaline degradations of polymer backbone in alkaline media [31]. AEMs based on aliphatic polymer backbones may lack thermal stability and mechanical strength. In contrast, PBI is a basic polymer with excellent thermal stability, high mechanical strength, and low water uptake. PBI even can be doped with a high concentration of $\mathrm{KOH}$ solution to obtain heterogeneous AEMs, namely $\mathrm{KOH}$-doped PBI $[32,33]$. Therefore, PBI is considered a good candidate as the polymer backbone alkaline stable for AEMs [34].

Aside from the development of hydrophilic ion transport channels, crosslinking is another common method capable of improving dimensional stability, mechanical strength and chemical stability of AEMs. However, the AEM's ion exchange capacity (IEC) may be decreased due to the incorporation of the crosslinker into it. Therefore, some research efforts have been made to develop silane-based quaternized crosslinkers consisting of cationic groups and silane groups that can undergo a sol-gel process to form organic-inorganic hybrid networks and provide additional anion conducting sites within the crosslinked AEMs [35-39]. For example, Li and his coworkers prepared a polysulfone based AEM crosslinked by 4,4'-oxydiphenylguanidinium-bridged-silsesquioxane (ODGBS) with an IEC of $2.47 \mathrm{mmol} \mathrm{g}^{-1}$ that exhibited a high hydroxide conductivity up to $2.5 \times 10^{-2} \mathrm{~S} \mathrm{~cm}^{-1}$ at $30^{\circ} \mathrm{C}$ [37]. In the work of Wang et al., their sol-gel-derived silica/PVA-Py hybrid AEMs had IEC ranging from $0.54 \mathrm{mmol} \mathrm{g}^{-1}$ to $0.92 \mathrm{mmol} \mathrm{g}^{-1}$ depending on the added amount of the quaternary ammonium-functionalized crosslinker [39].

Our previous study demonstrated that the side chain type quaternized PBI with methylimidazolium end-capped groups exhibited better alkaline stability and ionic conductivity compared with the main chain type quaternized PBI [40]. Recently, Lin and Ding et al. reported that the hydrophilic/hydrophobic micro-phase separation morphology can successfully form in the AEMs based on side chain type quaternized PBI containing dimethylimidazolium cations [24]. Wu and He et al. studied the influence of grafting strategies on the hydroxide conductivity and fuel cell performance for the AEMs based on side chain type quaternized PBI with quaternary ammounium end-capped groups [25]. Among these cations, dimethylimidazolium is expected to be more alkaline stable. The reason is that the C2-substituted methyl group of dimethylimidazolium can increase the steric interference and replace the acidic $\mathrm{C} 2$ protons to weaken the hydroxide attack, suggested by $\mathrm{Xu}$ and Yan's previous studies [41,42]. 
In the present work, we attempt to synthesize a new type of quaternized PBI-based AEMs using a combined strategy of quaternized side chain grafting and silane-induced crosslinking. A silane-based quaternized crosslinker (triethoxysilylpropyl dimethylimidazolium chloride, [SPDMIm] [Cl]) and a long flexible side chain containing dimethylimidazolium end group (bromohexyl dimethylimidazolium bromide, [BrHDMIm] [Br]) were synthesized and characterized. A side chain type dimethylimidazolium-functionalized PBI pristine membrane and its organic-inorganic hybrid membrane were prepared as AEMs for fuel cells. The morphology difference between the pristine and hybrid membranes was investigated. Membrane properties of AEMs including ion exchange capacity, water uptake, swelling ratio, hydroxide conductivity, and mechanical strength were measured. The thermal, alkaline, and oxidative stabilities of the prepared AEMs were evaluated. Furthermore, the fuel cell performance tests were carried out to confirm that the pristine and organic-inorganic hybrid membranes of dimethylimidazolium-functionalized PBI promising as AEMs for AEMFC applications.

\section{Materials and Methods}

\subsection{Materials}

3,3'-Diaminobenzidine (DAB), sodium hydride $(\mathrm{NaH})(\mathrm{dry}, 90 \%)$, polyphosphoric acid (PPA), and N,N-dimethylacetamide (DMAc) were received from Sigma-Aldrich. Phosphorous pentoxide $\left(\mathrm{P}_{2} \mathrm{O}_{5}\right)$ and sodium hydroxide $(\mathrm{NaOH})$ were provided by SHOWA and Alfa Aesar, respectively. 2,2-bis(4-carboxyphenyl)hexafluoropropane (6FDA) and 3-chloropropyltriethoxysilane were purchased from TCI. 3-chloropropyltrimethoxysilane (CPTMOS), 1,2-dimethylimidazole, 1,6-dibromohexane, N,N-dimethylacetamide (DMF), and dimethylsulfoxide (DMSO) (extra dry) were supplied from Acros Organics. All the reagents were ACS grade and used as received without further purifications. Nitrogen, hydrogen, and oxygen gases with a high purity of greater than $99.99 \%$ were provided from a local manufacturer (Jing-Shang gas).

\subsection{Synthesis of Polybenzimidazole (PBI)}

Polybenzimidazole (PBI) employed in this work was hexafluoroisopropylidene containing PBI, namely 6FPBI, synthesized from DAB and 6FDA in phosphoric acid containing extra $\mathrm{P}_{2} \mathrm{O}_{5}$. The detailed procedures followed our previous work $[43,44]$. The inherent viscosity of the synthesized PBI was measured to be $2.1 \mathrm{dL} / \mathrm{g}$ using a Ubbelohde tube viscometer in DMAc at $30^{\circ} \mathrm{C}$.

\subsection{Synthesis of Bromohexyl Dimethylimidazolium Bromide ([BrHDMIm] [Br])}

1,2-Dimethylimidazole (50 mmol), 1,6-dibromohexane $(60 \mathrm{mmol})$, and acetonitrile $(50 \mathrm{~mL})$ were added to a three-necked flask equipped with a condenser. The mixture was stirred with a magnetic stirrer at $60^{\circ} \mathrm{C}$ for $15 \mathrm{~h}$ under a nitrogen atmosphere. A viscous liquid formed after the mixture was added dropwise into an excess amount of diethyl ether under stirring. Then, the resulting viscous liquid was washed with ethyl acetate three times and was subsequently dried by evaporation under vacuum at $90^{\circ} \mathrm{C}$ for $24 \mathrm{~h}$. After that, a brown viscous liquid (BrHDMIm; Br) was obtained.

\subsection{Synthesis of Triethoxysilylpropyl Dimethylimidazolium Chloride ([SPDMIm] [Cl])}

1,2-Dimethylimidazole (50 mmol) and 3-chloropropyltrimethoxysilane (CPTMOS) $(50 \mathrm{mmol})$ were dissolved in DMF $(15 \mathrm{~mL})$ in a three-necked flask equipped with a condenser. The mixture was stirred under nitrogen at $80^{\circ} \mathrm{C}$ for $24 \mathrm{~h}$. After that, the mixture was poured into diethyl ether to obtain a viscous liquid. The resulting liquid was collected and washed with diethyl ether twice. After the resulting liquid was dried under vacuum at $75^{\circ} \mathrm{C}$ for $24 \mathrm{~h}$, a light yellow viscous liquid [SPDMIm] [Cl] was obtained. 


\subsection{Synthesis of Dimethylimidazolium-Functionalized Polybenzimidazole (PBI-DIm)}

PBI were dried in a vacuum oven at $100{ }^{\circ} \mathrm{C}$ overnight in advance. PBI $(2 \mathrm{mmol})$ was dissolved in anhydrous DMSO $(50 \mathrm{~mL})$ under nitrogen at $80^{\circ} \mathrm{C}$ in a three-necked flask equipped with a condenser. After cooling to room temperature, an excess $\mathrm{NaH}$ $(4.8 \mathrm{mmol})$ was added to the PBI solution. The solution kept stirring at $80^{\circ} \mathrm{C}$ for about $4 \mathrm{~h}$ until the bubbling stopped. After that, an excess amount of [BrHDMIm] [Br] (6 mmol) was added to the solution. The mixture was stirred under nitrogen at $80{ }^{\circ} \mathrm{C}$ for $24 \mathrm{~h}$. The resulting polymer was precipitated by pouring the mixture into an excess amount of acetone. A dimethylimidazolium-functionalized PBI (PBI-DIm) was obtained after the resulting polymer was washed with deionized water and dried in a vacuum oven at $90{ }^{\circ} \mathrm{C}$ for $24 \mathrm{~h}$. Meanwhile, the functionalization degree of the synthesized PBI-DIm was determined to be 1.93 pendant dimethylimidazolium groups per repeated unit by $1 \mathrm{H}$ NMR analysis.

\subsection{Fabrication of PBI-DIm Pristine Membranes and PBI-DIm-Si Hybrid Membranes}

A certain amount of PBI-DIm powders was dissolved in DMSO $(40 \mathrm{~mL})$ to make a $2 \mathrm{wt} \%$ polymer solution. To form PBI-DIm pristine membranes, the PBI-DIm solution $(20 \mathrm{~mL})$ was directly cast on a glass substrate and dried under a reduced pressure at $80^{\circ} \mathrm{C}$ for $12 \mathrm{~h}$ followed by a vacuum at $110^{\circ} \mathrm{C}$ for $12 \mathrm{~h}$. After peeling off the pristine membranes from the substrate, they were washed with methanol to remove any residual DMSO solvent and dried at $60{ }^{\circ} \mathrm{C}$ for $2 \mathrm{~h}$.

For preparing PBI-DIm-Si hybrid membranes, predetermined amounts of CPTMOS and [SPDMIm] [Cl] were added into the $2 \mathrm{wt} \%$ PBI-DIm solution $(20 \mathrm{~mL})$ in a sealed vial. The molar ratio of CPTMOS/[SPDMIm] [Cl]/PBI-DIm was fixed to be 0.1/0.1/1. A few drops of diethylamine and deionized water were added to the solution. Then, it was stirred at $50{ }^{\circ} \mathrm{C}$ for $24 \mathrm{~h}$ to promote the hydrolysis of silane groups. The solution was subsequently poured into a Petri dish with a cover and placed in an oven at $110{ }^{\circ} \mathrm{C}$ for $6 \mathrm{~h}$. After the cover of the Petri dish was taken away and the solution was dried under a reduced pressure at $110^{\circ} \mathrm{C}$ for $6 \mathrm{~h}$ followed by a vacuum at $110^{\circ} \mathrm{C}$ for $12 \mathrm{~h}$, the PBI-DIm-Si hybrid membranes were formed. After peeling off the hybrid membranes from the Petri dish, they were washed with methanol to remove any residual DMSO solvent and dried at $60{ }^{\circ} \mathrm{C}$ for $2 \mathrm{~h}$.

\subsection{Characterization}

${ }^{1} \mathrm{H}$ nuclear magnetic resonance (NMR) spectra for compound and polymer samples dissolved in DMSO- $\mathrm{d}_{6}$ were obtained on a Bruker AVANCE $600 \mathrm{MHz}$ spectrometer with a frequency of $600.3 \mathrm{MHz}$. Fourier transform infrared (FT-IR) spectra were recorded on a JASCO FT/IR 4600 spectrometer by scanning 16 times in a transmittance mode and a wavelength range between $400 \mathrm{~cm}^{-1}$ and $2000 \mathrm{~cm}^{-1}$ with a resolution of $2 \mathrm{~cm}^{-1}$. Thermogravimetric analysis (TGA) was recorded on a TA instrument model 2050 at a heating rate of $10^{\circ} \mathrm{C} / \mathrm{min}$ from $100{ }^{\circ} \mathrm{C}$ to $800{ }^{\circ} \mathrm{C}$ with a $20 \mathrm{~mL} / \mathrm{min}$ nitrogen flow. Thermomechanical analysis was performed to measure the in-plane coefficients of thermal expansion (CTEs) and glass transition temperatures (Tgs) of the membrane samples on a TA Instrument Q400EM. Atomic force microscopy (AFM) phase images were taken by mapping in a taping mode on a Bruckner Dimension ICON SPM at ambient temperature for observing the surface of the prepared membranes in their dry state. X-ray photoelectron spectroscopy (XPS) was conducted on a ULVAC PHI5000 VersaProbe instrument with a monochromatized Al $\mathrm{K} \alpha \mathrm{X}$-ray source generated by an electron beam $(24.7 \mathrm{~W})$. The XPSPEAK software version 4.1 was employed to deconvolute spectra into component peaks using a curve fitting method based on Gaussian Lorentzian sum functions. The background of the spectra was subtracted using the Shirley method. A scanning electron microscope (SEM) JEOL JSM5610 combined with an energy dispersive X-ray spectroscopy (EDX) system INCA supplied by Oxford Instruments was employed to carry out elemental mapping characterization. The cross-sectional SEM images of the membrane samples were taken by a high-resolution 
scanning electron microscope (HE-SEM), ITACHI SU8000. Small angle X-ray scattering (SAXS) analysis was performed on a Bruker NANOSTAR U SYSTEM equipped with a VANTEC-2000 detector.

\subsection{Measurements}

Ion exchange capacity (IEC) of a membrane was measured by the Mohr titration method. The membrane was immersed in $1 \mathrm{M} \mathrm{NaCl}$ solution at RT for $24 \mathrm{~h}$ to replace all anions in the membrane with $\mathrm{Cl}^{-}$ions for $24 \mathrm{~h}$. After washing with deionized water to remove any residual ions on the surface, the membrane was dried in a vacuum oven at $100{ }^{\circ} \mathrm{C}$ for $3 \mathrm{~h}$ and its dry weight was recorded. Afterward, the dry membrane was immersed in $1 \mathrm{M} \mathrm{Na}_{2} \mathrm{SO}_{4}$ solution at $\mathrm{RT}$ for $24 \mathrm{~h}$ for releasing $\mathrm{Cl}^{-}$ions to the solution. The amount of released $\mathrm{Cl}^{-}$ions was titrated with $0.1 \mathrm{M} \mathrm{AgNO}_{3}$ using $\mathrm{K}_{2} \mathrm{CrO}_{4}$ as a colorimetric indicator. The experimental IEC is calculated according to the following equation:

$$
\mathrm{IEC}=\frac{\mathrm{V}_{\mathrm{AgNO}_{3}} \times \mathrm{C}_{\mathrm{AgNO}_{3}}}{\mathrm{~m}_{\mathrm{dry}}}
$$

where $\mathrm{V}_{\mathrm{AgNO} 3}$ and $\mathrm{C}_{\mathrm{AgNO} 3}$ are the consumed volume and the concentration of $\mathrm{AgNO}_{3}$ solution. $\mathrm{m}_{\mathrm{dry}}$ is the weight of the dry membrane in $\mathrm{Cl}^{-}$form.

The water uptake (WU) and swelling ratio (SR) of a membrane were measured according to its weight and length changes in between the wet and dry states, respectively. Before measurement, the membrane was immersed in $1 \mathrm{M} \mathrm{KOH}$ solution at RT for $24 \mathrm{~h}$ to complete ion exchange, followed by washing with deionized water. After the membrane was picked out from the vial and wiped with tissue paper to remove surface water, the weight and length of the wet membrane $\left(W_{\text {wet }}\right.$ and $\left.L_{\text {wet }}\right)$ were measured. Then, it was dried in a vacuum oven at $100^{\circ} \mathrm{C}$ for $3 \mathrm{~h}$ and followed by measuring its weight and length in the dry state $\left(W_{d r y}\right.$ and $\left.L_{d r y}\right)$. The membrane's WU and SR is calculated as follows:

$$
\begin{aligned}
\mathrm{WU} & =\frac{W_{\text {wet }}-W_{d r y}}{W_{d r y}} \\
\mathrm{SR} & =\frac{L_{\text {wet }}-L_{d r y}}{L_{d r y}}
\end{aligned}
$$

The hydration number of a membrane $(\lambda)$ referring to the number of absorbed water molecules around each dimethylimidazolium group was calculated as follows.

$$
\lambda=\frac{10 \times W U(\%)}{18 \times I E C}
$$

The insoluble solid content of a membrane was determined by the dry weight change of a membrane before and after re-dissolved in DMSO. A membrane sample was redissolved in DMSO at RT for $72 \mathrm{~h}$ under gentle stirring. Then, the membrane was immersed in excess methanol for $12 \mathrm{~h}$ to leach DMSO from it. The resulting membrane was dried under vacuum at $60{ }^{\circ} \mathrm{C}$ for $12 \mathrm{~h}$. The insoluble solid content of the membrane can be determined according to the equation below.

$$
\text { Insoluble solid content } \frac{W_{d r y}-W_{d r y . r e-d i s s o l v e d}}{W_{d r y}}
$$

The terms $W_{d r y}$ and $W_{d r y, r e-d i s s o l v e d}$ are referred to as the weight of the dry membrane before and after being re-dissolved in DMSO, respectively.

\subsection{Hydroxide Conductivity and Alkaline Stability}

The hydroxide conductivity of a membrane was measured using the electrochemical impedance spectroscopy method, which was conducted on an Autolab PGSTAT128N 
impedance analyzer connected to a 4-electrode cell (BekkTech BT-112) over the frequency range from $10^{2} \mathrm{~Hz}$ to $10^{5} \mathrm{~Hz}$ with an alternating voltage amplitude of $10 \mathrm{mV}$. Before measurement, the membrane was immersed in $1 \mathrm{M} \mathrm{KOH}$ solution at RT for $24 \mathrm{~h}$ to complete ion exchange, followed by washing with deionized water. The membrane sample in a $30 \mathrm{~mm} \times 4.5 \mathrm{~mm}$ dimension was inserted in the 4-electrode cell, which was placed in $\mathrm{N}_{2}$-saturated deionized water in a sealed flask. The in-plane hydroxide conductivity was calculated by the following equation.

$$
\sigma=\frac{L}{A \times R_{\Omega}}
$$

where $\sigma$ is the in-plane hydroxide conductivity of the fully hydrated membrane $\left(\mathrm{S} \mathrm{cm}^{-1}\right) . L$ is the length between the two voltage measuring probes $(0.425 \mathrm{~cm})$. $A$ is the cross-sectional area perpendicular to the current flow $\left(\mathrm{cm}^{2}\right) . R_{\Omega}$ is the ohmic resistance of the membrane, obtained from the approximate value of the real impedance-axis intercept in a Nyquist plot.

The alkaline stability of the membrane was evaluated by the change in hydroxide conductivity during an alkaline treatment that is carried out by immersing the $\mathrm{OH}^{-}$ form membrane in $2 \mathrm{M} \mathrm{KOH}$ at $80{ }^{\circ} \mathrm{C}$ for $120 \mathrm{~h}$. Before each hydroxide conductivity measurement, the membrane sample was washed with deionized water several times and kept in $\mathrm{N}_{2}$-saturated deionized water for at least $12 \mathrm{~h}$.

\subsection{Mechanical Properties and Oxidative Stability}

Mechanical properties of a membrane sample were examined on a Shimadzu AG-SI universal testing machine at a $20 \mathrm{~mm} / \mathrm{min}$ tensile testing speed under ambient conditions. The samples were prepared at $50 \mathrm{~mm}$ in length, $4.5 \mathrm{~mm}$ in width, and approximately $30-40 \mu \mathrm{m}$ in thickness. Each result is the average value for at least six samples. The oxidative stability of a membrane was evaluated using the Fenton test. The membrane was immersed in a $3 \mathrm{wt} \%$ hydrogen peroxide aqueous solution containing $4 \mathrm{ppm} \mathrm{Fe}^{2+}$ at $80{ }^{\circ} \mathrm{C}$. The remaining weight of the degraded membrane in the dry state was recorded every $2 \mathrm{~h}$.

\subsection{Fuel Cell Tests}

A catalyst ink was prepared by mixing a Pt/C catalyst $\left(\right.$ VULCAN $^{\circledR}$ XC-72R/Cabot, College Station, Texas, TX, USA, $40 \mathrm{wt} \% \mathrm{Pt}$ ) with an ionomer solution (Sustainion ${ }^{\circledR} \mathrm{XB}-$ $7 /$ Dioxide Materials, Boca Raton, FL, USA, alkaline ionomer $5 \%$ in ethanol) and an aqueous isopropyl alcohol solution. The solid content ratio of the ionomer to the $\mathrm{Pt} / \mathrm{C}$ catalyst was 1:4. The catalyst ink was sonicated for $5 \mathrm{~min}$ in an ice bath with a probe-type sonicator. Subsequently, it was coated onto carbon papers (N1S1007/QuinTech Indiana, PA, USA) on a hot plate by drop-casting to prepare gas diffusion electrodes (GDEs) at a Pt loading of $0.8 \mathrm{mg} \mathrm{cm}^{-1}$. Three AEMs in OH form including the PBI-DIm membrane, PBI-DIm-Si hybrid membrane, and the commercially available AEM Sustainion ${ }^{\circledR}$ X37-RT (purchased from Dioxide Materials, Inc.) were individually sandwiched between two GDEs without hot-pressing to fabricate their membrane electrode assemblies (MEAs). The effective area of the MEAs was $4 \mathrm{~cm}^{2}$. The fuel cell performance of the MEA at $60{ }^{\circ} \mathrm{C}$ under ambient pressure was examined in a fuel cell test system (Tension Energy, Inc., Zhubei, TaiWan) equipped with an electronic load unit controller. The flow rates of the humidified hydrogen and oxygen were controlled to be $50 \mathrm{~mL} \mathrm{~min}^{-1}$ and $100 \mathrm{~mL} \mathrm{~min}^{-1}$, respectively.

\section{Results and Discussion}

\subsection{Synthesis and Characterization}

In this work, we synthesized two dimethylimidazolium based ionic liquids [BrHD$\mathrm{MIm}][\mathrm{Br}]$ and [SPDMIm] [Cl] by the Menshutkin reaction as shown in Scheme 1. [BrHDMIm] [Br] was grafted onto PBI by the $S_{N} 2$ reaction to obtain side chain type quaternized PBI, denoted PBI-DIm. The functionalization degree of PBI-DIm was determined to be 1.93 (dimethylimidazolium groups per repeated unit) by ${ }^{1} \mathrm{H}$ NMR integration analysis. The functionalization degree of less than 2 implied that no alkaline unstable benzimidazolium 
groups in the polymer main chain formed. Meanwhile, PBI-DIm still had some sites for the further grafting of silane pendant groups (CPTMOS). As presented in Scheme 2, the appropriate amount of [SPDMIm] [Cl] and CPTMOS was introduced into PBI-DIm to carry out a crosslinking reaction involving hydrolysis and condensation processes for preparing a quaternized PBI organic-inorganic hybrid (PBI-DIm-Si hybrid). This silane-induced crosslinking reaction underwent along with the membrane casting process in order to obtain homogeneous membranes.

(a)

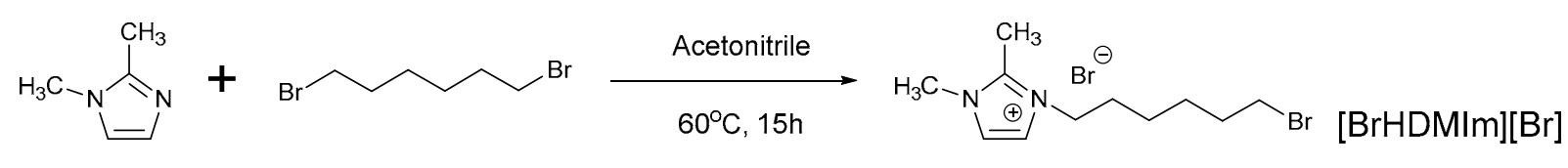

(b)

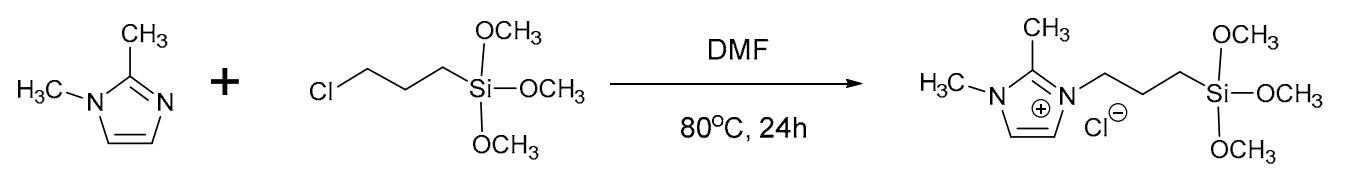

[SPDMIm][Cl]

Scheme 1. Synthetic routes of (a) [BrHDMIm] [Br] and (b) [SPDMIm] [Cl].

The chemical structures of [BrHDMIm] [Br], [SPDMIm] [Cl], PBI, and PBI-DIm were confirmed by ${ }^{1} \mathrm{H}$ NMR analysis as shown in Figure 1. All the signals of PBI were in accordance with those reported in the previous studies [40]. The characteristic signals $\left(\mathrm{H}_{2}\right)$ corresponding to the aliphatic methylene protons adjacent to dimthylimidazolium for [BrHDMIm] [mBr], [SPDMIm] [Cl], and PBI-DIm appeared at the chemical shift at $4.10 \mathrm{ppm}, 4.20 \mathrm{ppm}$, and $4.03 \mathrm{ppm}$, respectively. Meanwhile, the signals attributed to the methyl protons of dimthylimidazolium moiety $\left(\mathrm{H}_{3}\right.$ and $\left.\mathrm{H}_{5}\right)$ for [BrHDMIm] [Br], [SPDMIm] [Cl], and PBI-DIm were located at around 3.7-3.8 ppm and 2.5-2.7 ppm. In the PBI-DIm spectrum, we found that an additional signal $\left(\mathrm{H}_{2^{\prime}}\right)$ at the chemical shift from $4.35 \mathrm{ppm}$ to $4.6 \mathrm{ppm}$ ascribed to the methylene protons nearby the nitrogen of benzimidazole was present, but the signal $\left(\mathrm{H}_{4}\right)$ for [BrHDMIm] [Br] corresponding to the methylene protons adjacent to bromine at $3.51 \mathrm{ppm}$ was absent. This finding suggested that the grafting of [BrHDMIm] [Br] onto PBI backbone by covalent bonding has taken place. The other signals $\left(\mathrm{H}_{6}, \mathrm{H}_{7}, \mathrm{H}_{7^{\prime}}, \mathrm{H}_{8}\right.$, and $\left.\mathrm{H}_{8^{\prime}}\right)$ related to the methylene protons of [BrHDMIm] [Br], [SPDMIm] [Cl], and PBI-DIm were individually assigned in the chemical shift range of $0.3 \mathrm{ppm}$ and 1.9 ppm, as seen in Figure 1.

The FTIR spectra of the PBI, PBI-DIm, and PBI-DIm-Si hybrid membranes were compared in Figure 2. The characteristic absorption band corresponding to the $\mathrm{N}=\mathrm{C}-\mathrm{N}$ stretching vibration of the imidazolium moiety was observed at $1536 \mathrm{~cm}^{-1}$ in both spectra of PBI-DIm and PBI-DIm-Si hybrid [45]. Meanwhile, the absorption band attributed to the $\mathrm{C}=\mathrm{N}$ stretching vibration of the benzimidazole moiety was noticed to shift from $1630 \mathrm{~cm}^{-1}$ (for PBI) to $1620 \mathrm{~cm}^{-1}$ (for PBI-DIm and PBI-DIm-Si hybrid). This slight shift may arise from the grafting of the side chains onto PBI, in line with the previous finding [40]. The alkane $\mathrm{C}-\mathrm{H}$ stretching vibrations of methylene and methyl groups belonging to the dimethylimidazolium side chains of PBI-DIm and PBI-DIm-Si hybrid resulted in two absorption bands at $2861 \mathrm{~cm}^{-1}$ and $2940 \mathrm{~cm}^{-1}$. Moreover, the band due to the asymmetric $\mathrm{Si}-\mathrm{O}-\mathrm{Si}$ stretching vibration usually appears in the region between $1130 \mathrm{~cm}^{-1}$ and $1030 \mathrm{~cm}^{-1}$ can be found only in the spectrum of PBI-DIm-Si hybrid [46]. This finding indicated that the hydrolysis and condensation occurred during the sol-gel process. 


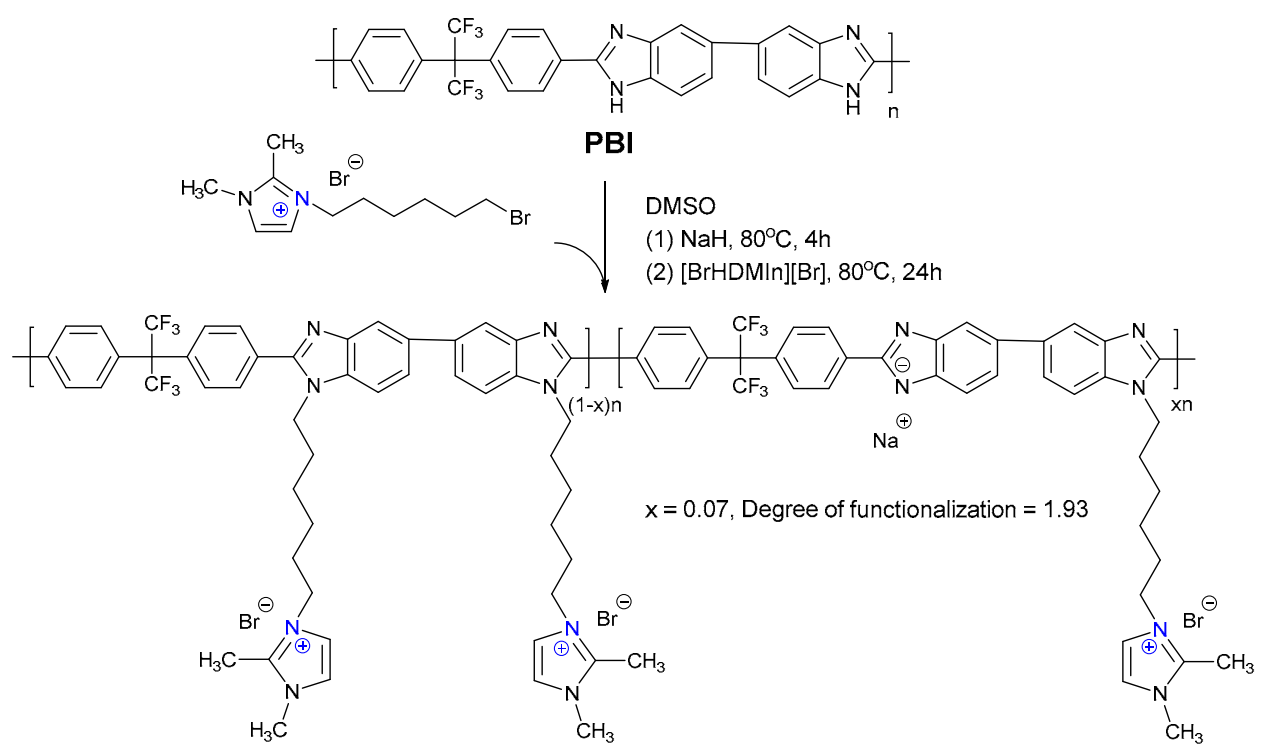

PBI-DIm

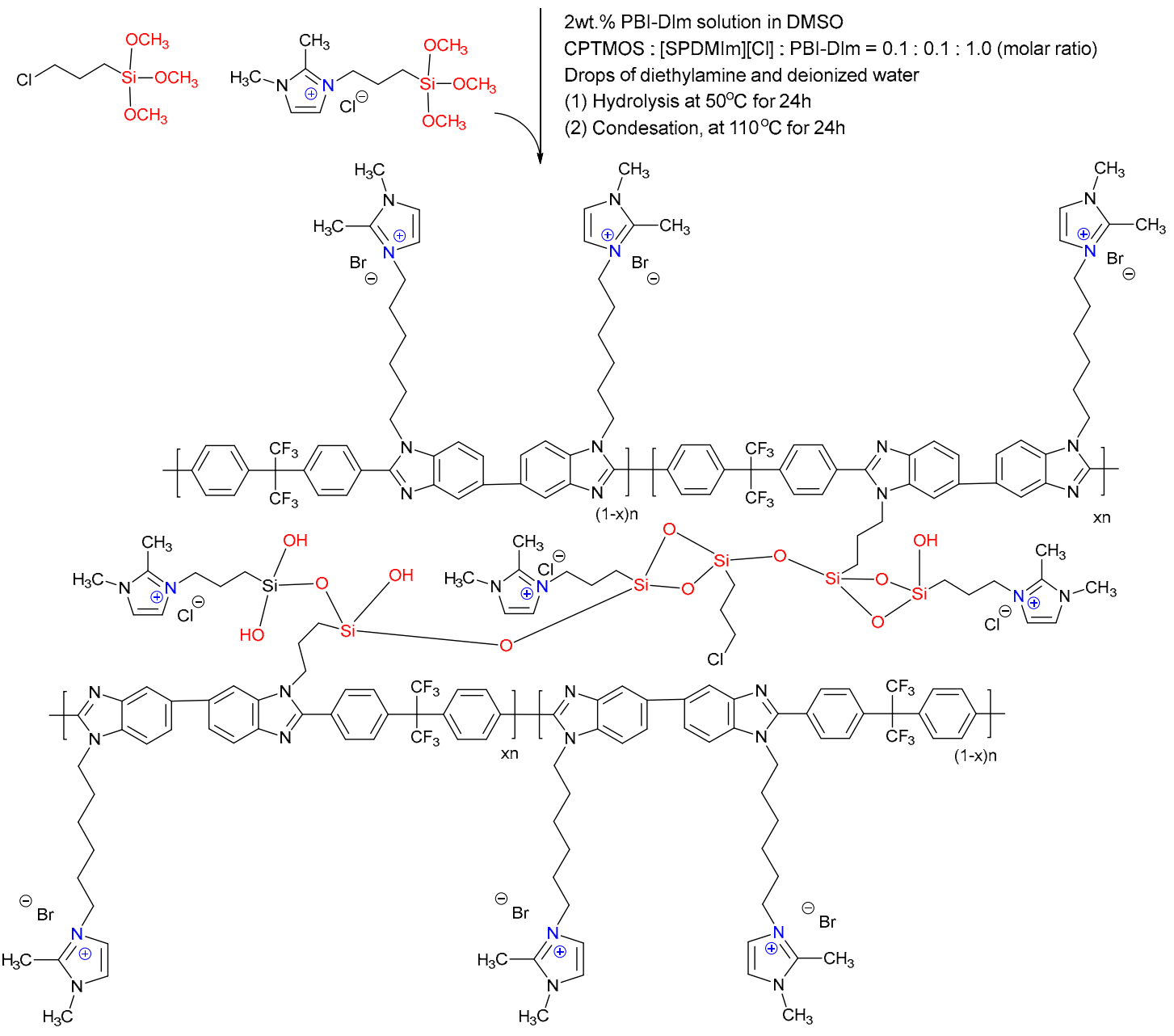

PBI-DIm-Si hybrid

Scheme 2. Synthetic route of PBI-DIm and PBI-DIm-Si hybrid. 


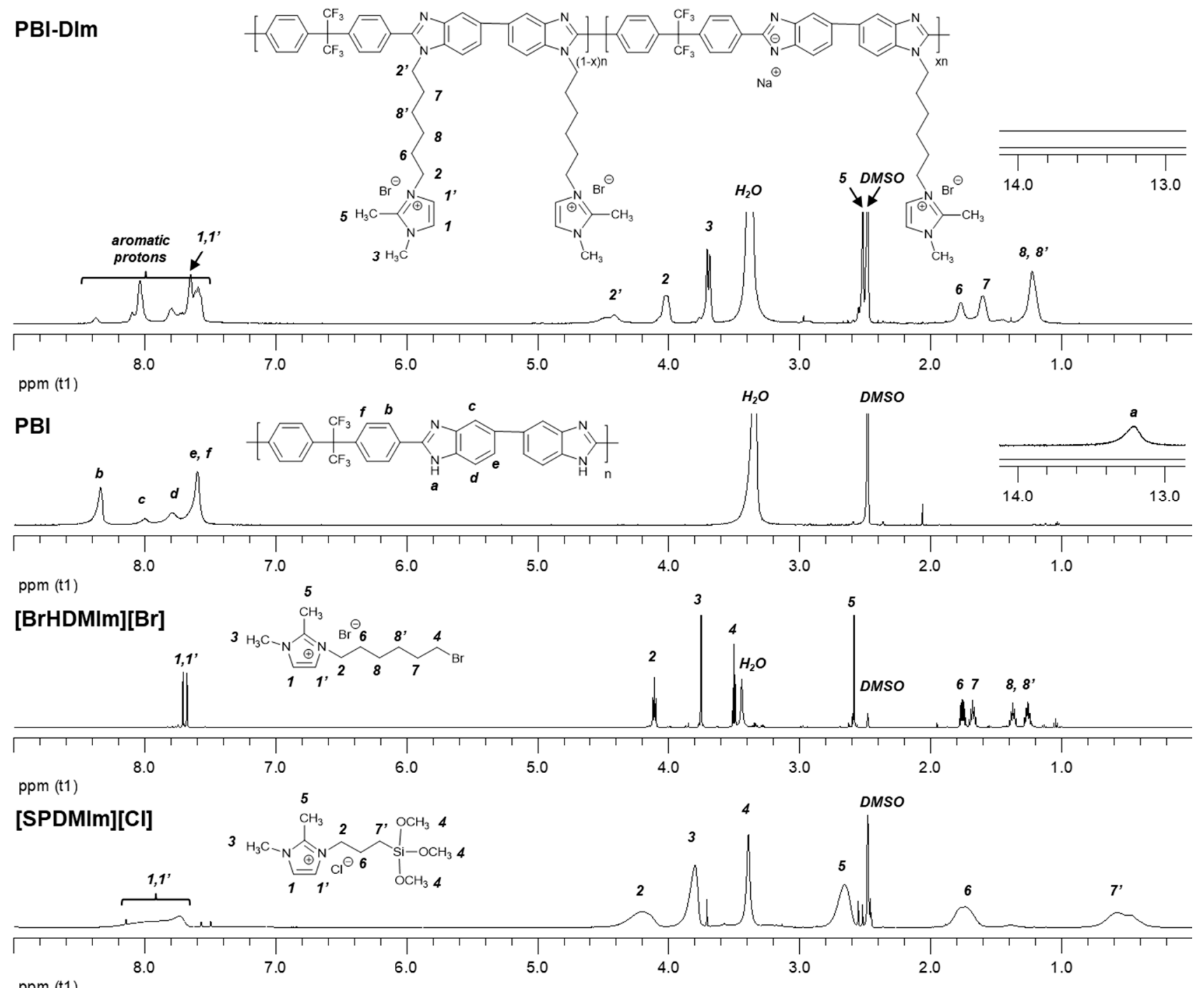

Figure 1. ${ }^{1} \mathrm{H}$ NMR spectra of [SPDMIm] [Cl], [BrHDMIm] [Br], PBI, and PBI-DIm.

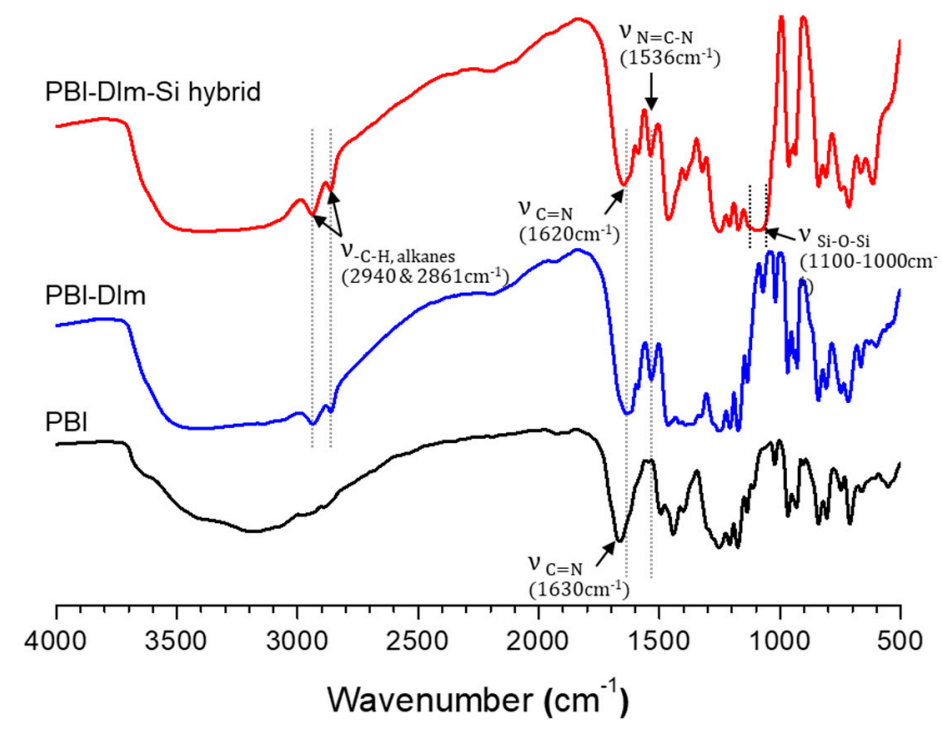

Figure 2. FTIR spectra of PBI, PBI-DIm, and PBI-DIm-Si hybrid membranes. 
Compared with PBI polymer backbone, imidazolium cations are relatively unstable and possible to undergo thermal degradation when the temperature exceeds $250^{\circ} \mathrm{C}[47,48]$. Figure 3a presented the TGA curves of the PBI, PBI-DIm, and PBI-DIm-Si hybrid membranes recorded from $100{ }^{\circ} \mathrm{C}$ to $800{ }^{\circ} \mathrm{C}$. As expected, the weight loss in the temperature range approximately between $250{ }^{\circ} \mathrm{C}$ and $400{ }^{\circ} \mathrm{C}$ due to the decomposition of dimethylimidazolium side chains was detected for PBI-DIm and PBI-DIm-Si hybrid. The weight loss at the temperature above $500{ }^{\circ} \mathrm{C}$ attributed to the decomposition of the PBI main chains can be found for the three thermograms. Moreover, the decomposition temperature of $5 \mathrm{wt} . \%$ weigh loss $\left(\mathrm{T}_{\mathrm{d} 5}\right)$ of PBI-DIm-Si hybrid was noticed to be slightly higher than that of the PBI-DIm.

(a)

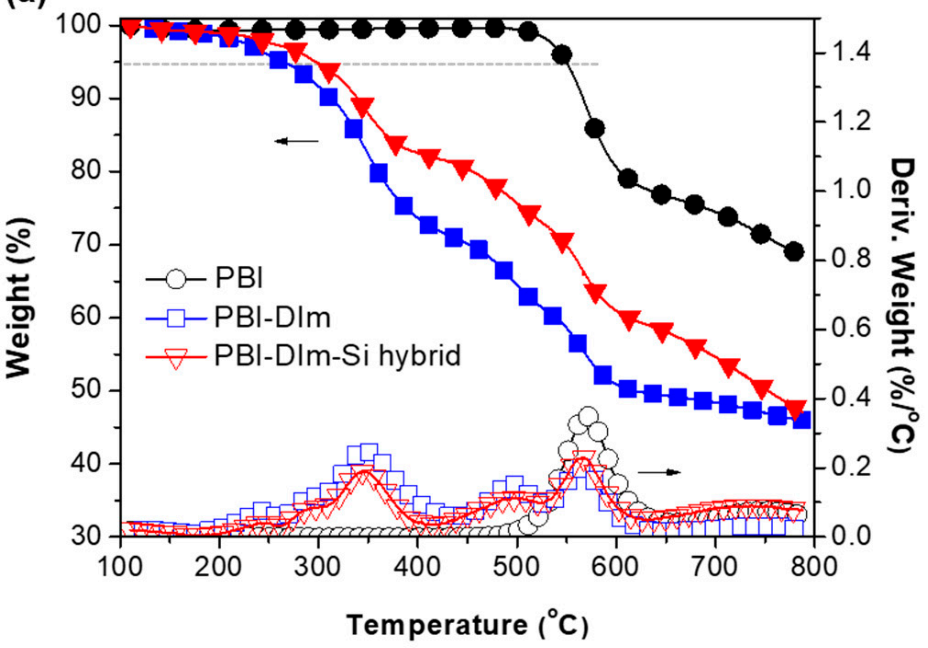

(b)

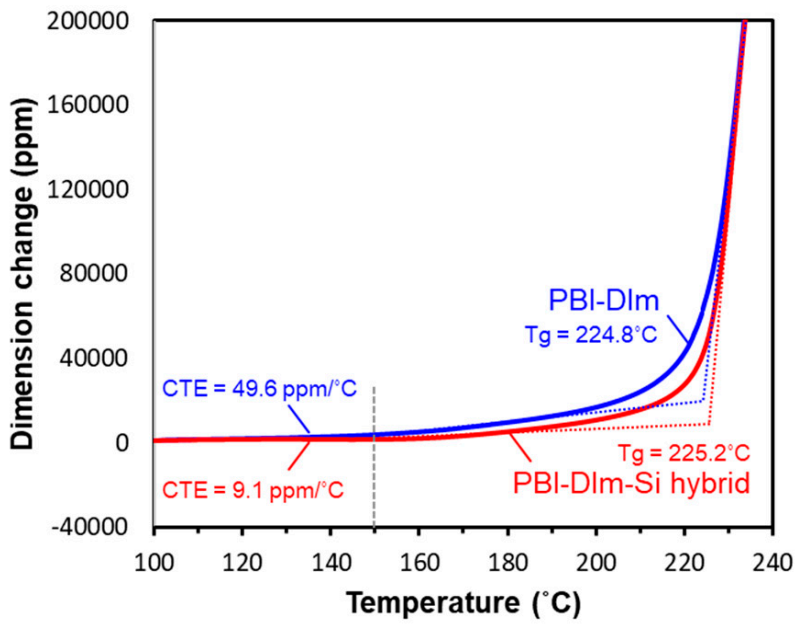

Figure 3. (a) Thermograms of PBI, PBI-Dim, and PBI-DIm-Si hybrid membranes in a temperature range from $100{ }^{\circ} \mathrm{C}$ to $800{ }^{\circ} \mathrm{C}$ under a nitrogen atmosphere. (b) Dimension changes of the PBI-DIm and PBI-DIm-Si hybrid membranes as a function of temperature.

A thermomechanical analysis (TMA) can be used to determine the glass transition temperatures (Tg) and the coefficient of thermal expansion (CTE) of a membrane. Figure $3 \mathrm{~b}$ shows the dimension changes of the PBI-DIm and PBI-DIm-Si hybrid membranes as a function of temperature. Notably, the Tgs of these two membranes were almost the same $\left(224.8^{\circ} \mathrm{C}\right.$ and $\left.225.2^{\circ} \mathrm{C}\right)$, but the difference between their CTEs was considerable. The CTE of the PBI-DIm-Si hybrid membrane in the temperature range from $100{ }^{\circ} \mathrm{C}$ to $150{ }^{\circ} \mathrm{C}$ was determined to be $9.1 \mathrm{ppm} /{ }^{\circ} \mathrm{C}$, much lower than that of PBI-DIm membrane $\left(49.6 \mathrm{ppm} /{ }^{\circ} \mathrm{C}\right)$ and the CTEs of most of the semi-crystalline polymers [49]. This finding suggested that the organic-inorganic hybrid structure is beneficial for the dimensional stability of the membrane when the temperature varies below the quaternized PBI's Tg.

\subsection{Membrane Morphology}

It can be seen that both the appearance of PBI-DIm and PBI-DIm-Si hybrid membranes were transparent and homogeneous (Figure 4a). Additionally, quite smooth and dense surfaces of these two membranes were observed from their SEM cross-sectional micrographs in Figure $4 \mathrm{~b}$, revealing that their gas separation for hydrogen and oxygen gases would function well. 
(a)

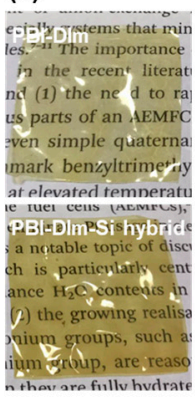

(b)

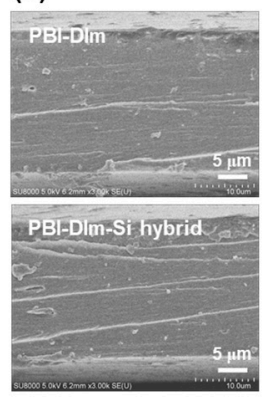

(c)

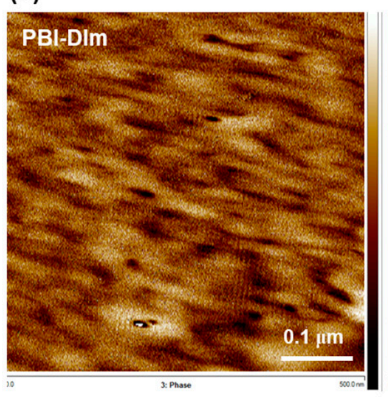

(d)

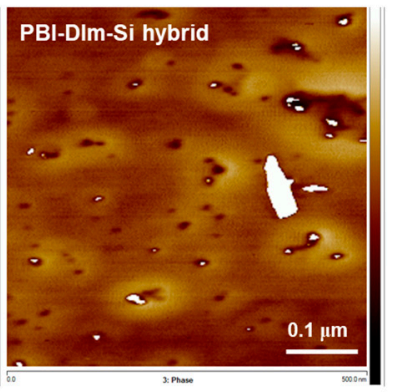

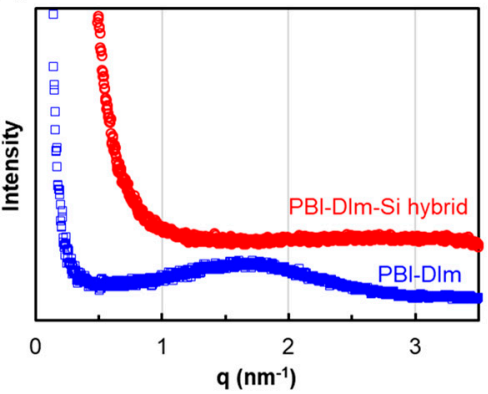

Figure 4. (a) Photographs, (b) SEM cross-sectional micrographs, (c) AFM phase images of the PBI-DIm and PBI-DIm-Si hybrid membranes, and (d) SAXS profiles of PBI-DIm and PBI-DIm-Si hybrid membranes.

AFM in a tapping mode was employed further to characterize the surface morphology of the as-prepared membranes. For side chain type AEMs, the immiscibility between hydrophilic side chains and hydrophobic polymer backbone may contribute to microphase separations and fabrication of hydrophilic channels beneficial for ion transports ${ }^{19}$. As shown in Figure 4c, we observed a distinguishable hydrophilic/hydrophobic phase separation in the AFM phase image of the PBI-DIm membrane in a scan area of $500 \mathrm{~nm} \times 500 \mathrm{~nm}$. The darker regions represented hydrophilic domains constructed by the ionic clusters of the dimethylimidazolium side chains, whereas the brighter regions were the hydrophobic domains comprising the PBI main chain ${ }^{41}$. In contrast, the phase separation was unclear, and many white spots were present in the PBI-DIm-Si hybrid membrane. The hydrophilic/hydrophobic phase separations appeared to be interrupted by the organicinorganic hybrid networks. The presence of white spots would result from the formation of the silica-based component during the sol-gel process.

The SAXS diffraction technique can be used to analyze the average ionic cluster dimension in anion exchange membranes [50]. As shown in Figure 4d, a broad ionic peak can be observed from the SAXS diffraction profile of PBI-DIm, indicating that an ordered structure due to the hydrophilic/hydrophobic phase separation has been developed within the quaternized PBI pristine membrane. The maximum scattering peak position was approximately at $1.66 \mathrm{~nm}^{-1}$, which corresponded to the interdomain Bragg spacing of $3.79 \mathrm{~nm}$. Meanwhile, there was no SAXS scattering peak for the PBI-DIm-Si hybrid membrane, in line with the AFM result. Both AFM and SAXS results suggest the aggregation of ionic clusters successfully occurred in the PBI-DIm pristine membrane, which could facilitate the development of the hydrophilic ion transport channels. As a result, it can be expected that the ionic conduction will be faster in the pristine membrane than in the hybrid membrane.

Using EDX elemental mapping technique (Figure 5a), the silicon element was observed uniformly dispersed within the PBI-DIm-Si hybrid. Moreover, Figure $5 b, c$ show the XPS full spectrum and high-resolution spectrum of Si $2 p$ core-level peak for the PBI-DIm-Si hybrid membrane. The Si $2 p$ peak can be deconvoluted into two sub-peaks at $101.7 \mathrm{eV}$ for silane and $103.3 \mathrm{eV}$ for silica [51], revealing that the partial silicon element was converted from organic silane to inorganic silica. This result confirmed the formation of the silica-based component in the hybrid membrane.

\subsection{Ion Exchange Capacity, Water Uptake and Swelling Ratio}

The experimental IECs of PBI-DIm and PBI-DIm-Si hybrid, measured by the Mohr titration method for their $\mathrm{Cl}^{-}$form membranes, agreed with their theoretical IECs listed in Table 1. Owing to some additional dimthylimidazolium cations coming from (SPDMIm; $\mathrm{Cl})$, the IEC of PBI-DIm-Si hybrid $\left(1.87 \mathrm{mmol} \mathrm{g}^{-1}\right)$ was found slightly higher than that of PBI-DIm $\left(1.85 \mathrm{mmol} \mathrm{g}^{-1}\right)$ as expected. 
(a)

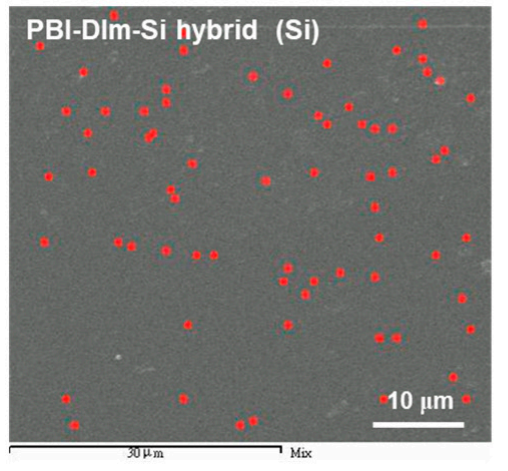

(b)

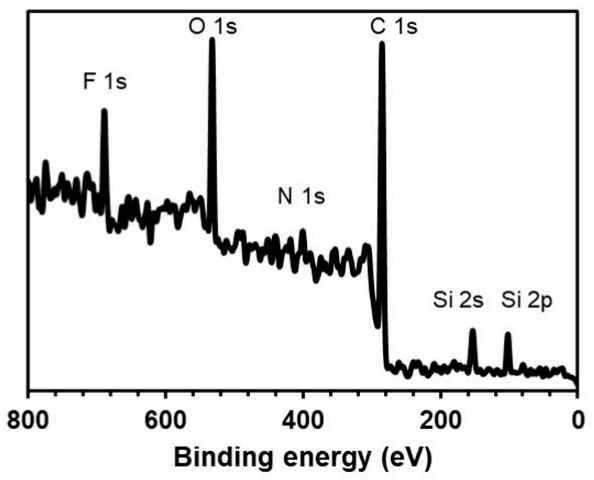

(c)

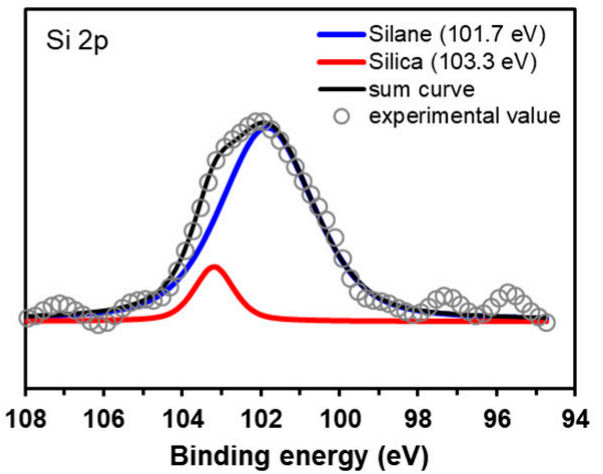

Figure 5. (a) EDX elemental mapping (red: silicon), (b) XPS full spectrum, and (c) high-resolution spectrum of Si 2p core-level peak for the PBI-DIm-Si hybrid membrane.

Table 1. Properties of the PBI-DIm and PBI-DIm-Si hybrid membranes.

\begin{tabular}{|c|c|c|c|c|c|c|}
\hline AEM & $\begin{array}{c}\text { Theoretical IEC }{ }^{1} \\
\text { (mmol/g) }\end{array}$ & $\begin{array}{c}\text { Experimental } \text { IEC }^{4} \\
(\mathrm{mmol} / \mathrm{g})\end{array}$ & $\begin{array}{c}\text { WU }^{5} \\
(\%)\end{array}$ & $\begin{array}{l}\mathrm{SR}^{5} \\
(\%)\end{array}$ & $\lambda$ & $\begin{array}{l}\text { Insoluble Solid } \\
\text { Content (wt } \%)\end{array}$ \\
\hline PBI-DIm & $2.02^{2}$ & 1.85 & 62.7 & 26.7 & 18.8 & 62.4 \\
\hline PBI-DIm-Si hybrid & $2.05^{3}$ & 1.87 & 30.9 & 10.0 & 9.2 & 78.8 \\
\hline
\end{tabular}

${ }^{1}$ determined for the $\mathrm{Cl}^{-}$form membrane. ${ }^{2}$ calculated from the functionalization degree of PBI-DIm. ${ }^{3}$ calculated from the molar ratio of CPTMOS: [SPDMIm] [Cl]: PBI-DIm. ${ }^{4}$ measured by Mohr titration for the $\mathrm{Cl}^{-}$form membrane. ${ }^{5}$ determined for the $\mathrm{OH}^{-}$form membrane.

The water uptake of an AEM is essential for ion dissociation and ion conduction, which is affected by the IEC and the chemical structure of the polymer. However, excessive water uptake by the membrane would lead to poor dimensional stability and weak mechanical properties [52]. However, the side chain type AEM based on PBI-DIm with high IEC exhibited moderate water uptake $(\mathrm{WU}=62.7 \%$ ) and swelling ratio $(\mathrm{SR}=26.7 \%)$, owing to the PBI backbone containing hydrophobic hexafluoroisopropylidene moiety. Notably, the WU and SR further declined to $30.9 \%$ and $10.0 \%$ for the PBI-DIm-Si hybrid membrane. The reason may lie in the fact that organic-inorganic hybrid networks reduced the water affinity of the membrane [53]. Additionally, the swelling ratios of these two membranes were lower than the reported value of Nafion 117 (28\%) [54], suggesting that their dimensional stabilities were adequate for fuel cell applications.

The hydration number $(\lambda)$, determined by the ratio of experimental IEC and WU values, represents the number of water molecules around each cationic group. PBI-DIm had a relatively high hydration number (18.8), about twice higher than that of PBI-DIm-Si hybrid. This result can explain why the hydrophilic channels beneficial for ion conduction were successfully developed in the PBI-DIm membrane (Figure 4c).

It is noticed that the as-prepared AEMs cannot re-dissolve in the casting solvent DMSO. The intermolecular interactions between dimethylimidazolium cationic groups in the side chain and deprotonated bezimidazole anionic groups in the main chain through ionic attraction, as illustrated in Scheme 3, could be the possible reason for the reduced solubility of the quaternized PBI in DMSO [25,55]. The insoluble solid content of the PBI-DIm and PBI-DIm-Si hybrid membranes were measured to be $62.4 \mathrm{wt} \%$ and $78.8 \mathrm{wt} \%$, respectively. As expected, the crosslinking networks of the PBI-DIm-Si hybrid membrane further increase its insoluble gel fraction. 


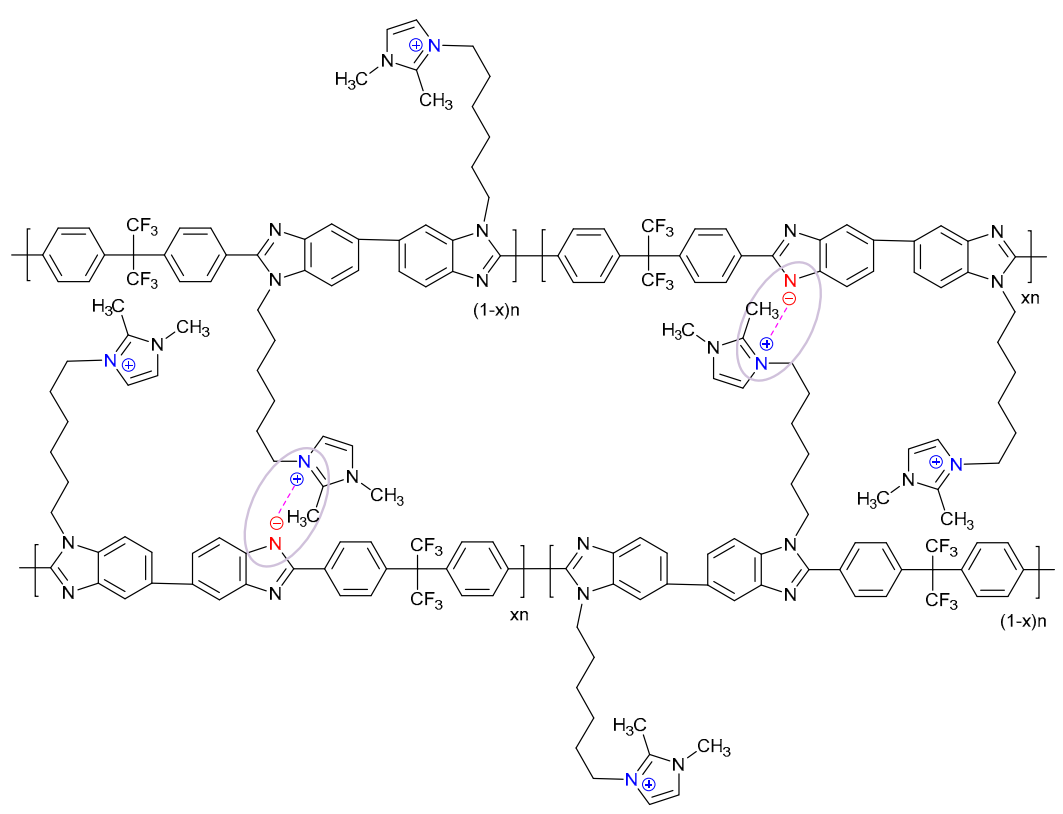

Scheme 3. Possible intermolecular interactions between PBI-DIm.

\subsection{Hydroxide Conductivity and Alkaline Stability}

The hydroxide conductivity of an AEM has a decisive influence on the fuel cell performance. In this work, we employed a 4-electrode method to conduct the hydroxide conductivity measurements for the $\mathrm{OH}^{-}$form membranes under fully hydrated conditions. Generally, the hydroxide conductivity of AEM higher than $10^{-2} \mathrm{~S} \mathrm{~cm}{ }^{-1}$ for better fuel cell performance is required [56]. As shown in Figure 6a,b, the measured hydroxide conductivity highly depended on temperature, obeying the Arrhenius law quite well. In the temperature range of $30^{\circ} \mathrm{C}$ and $80{ }^{\circ} \mathrm{C}$, the hydroxide conductivity of the PBI-DIm membrane increased from $1.52 \times 10^{-2} \mathrm{~S} \mathrm{~cm}^{-1}$ to $5.02 \times 10^{-2} \mathrm{~S} \mathrm{~cm}^{-1}$, whereas that of the PBI-DIm-Si hybrid membrane was measured varying from $6.36 \times 10^{-3} \mathrm{~S} \mathrm{~cm}^{-1}$ to $2.22 \times 10^{-2} \mathrm{~S} \mathrm{~cm}^{-1}$. Despite these two membranes having similar IECs, PBI-DIm exhibited relatively higher hydroxide conductivities than PBI-DIm-Si hybrid, which may be due to the morphology of hydrophilic/hydrophobic micro-phase separations that facilities the ion transport more effectively [20]. Moreover, the activation energy of hydroxide transport for the PBI-DIm and PBI-DIm-Si hybrid membranes can be obtained by means of the Arrhenius plots. The difference between their activation energies was found insignificant. This finding implied that the hydroxide transport mechanism was the same for these two membranes with different morphologies. It is known that the hydroxide can transport in AEMs via either the vehicular mechanism or the Grotthuss mechanism [57]. Previous studies suggested that the ion transport will obey vehicular mechanism if the activation energy is less than $14 \mathrm{~kJ} \mathrm{~mol}^{-1}[58,59]$. Since the activation energies in these two membranes exceed $14 \mathrm{~kJ} \mathrm{~mol}^{-1}$, the Grotthuss mechanism is supposed to dominate the ion transport mechanism [60].

The alkaline stability of the AEMs based on dimethylimidazolium-functionalized PBI was evaluated by monitoring the change in hydroxide conductivity during the alkaline treatment which was conducted by immersing the membrane samples in $2 \mathrm{M} \mathrm{KOH}$ aqueous solution at $80^{\circ} \mathrm{C}$ for $120 \mathrm{~h}$. As shown in Figure 6c, there is almost no decay in hydroxide conductivity measured at $30^{\circ} \mathrm{C}$ during the alkaline treatment for these two AEMs, indicating that they were alkaline stable and promising for practical applications in AEMFCs. The main reason may lie in the fact that the methyl-protecting groups at the C2-position of the imidazolium ring positively affect the alkaline stability of the membrane to prevent the ring-opening hydrolysis under strong alkaline conditions [61]. Recently, Dekel and his co-workers reported that lowing hydration number or water content would 
accelerate the degradation rate of cationic groups (e.g., benzyl trimethylammonium) and decrease the activation energy of hydroxide attack in the AEMs [62]. Accordingly, in our case, excess water in the vicinity of the cationic side groups (i.e., high $\lambda$ ) diluting the hydroxide ion concentration may weaken the nucleophilic attack of hydroxide ions to dimthylimidazolium, especially for the PBI-DIm membrane. Aside from these reasons, the crosslinked structure of the PBI-DIm-Si hybrid membrane may account for enhancing the membrane's alkaline stability.

(a)

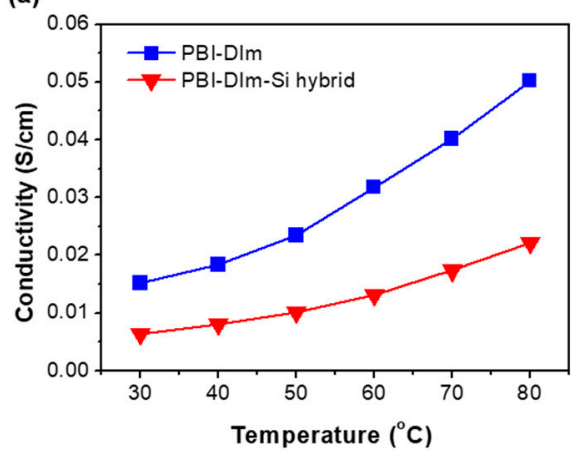

(b)

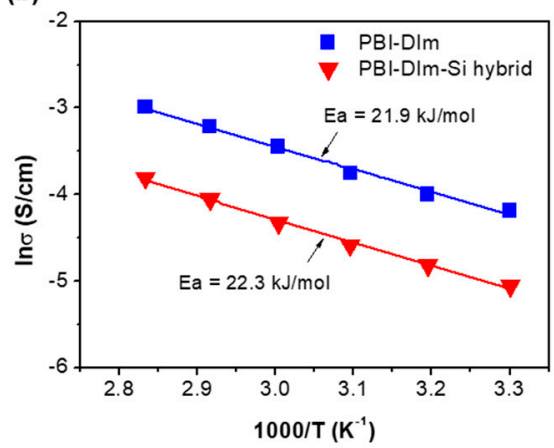

(c)

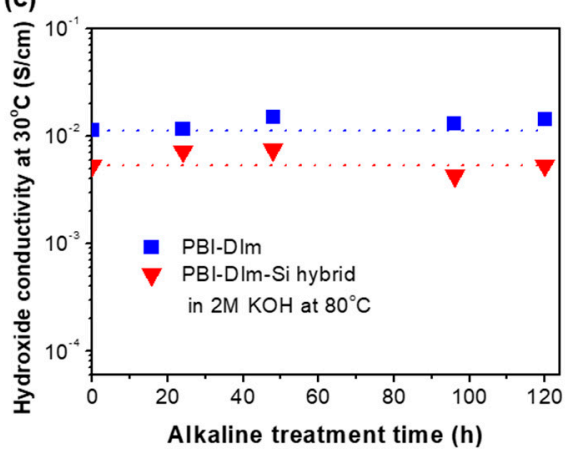

Figure 6. (a)Temperature dependence of hydroxide conductivity, (b) the Arrhenius plot, and (c) hydroxide conductivity measured at $30^{\circ} \mathrm{C}$ as a function of time during the alkaline treatment in $2 \mathrm{M} \mathrm{KOH}$ at $80^{\circ} \mathrm{C}$, for the PBI-DIm and PBI-DIm-Si hybrid membranes.

\subsection{Mechanical Properties and Oxidative Stability}

In general, ion conduction in AEMs under fully hydrated conditions functions better than under dry conditions. However, the excess water could impair the mechanical properties of AEMs, which is unfavorable for fabricating robust membrane electrode assemblies (MEAs). On the other hand, the gas diffusion electrode at the cathode undergoing the electrochemical reaction may generate lots of oxygen-related radicals during the fuel cell operation, which will attack the polymer backbone of AEM, leading to degradations [63,64]. Therefore, sufficient mechanical strength and adequate oxidative stability of AEMs are of importance for the long-term operation of fuel cells $[65,66]$.

The mechanical properties of the PBI-DIm and PBI-DIm-Si hybrid membranes in the dry and fully hydrated states were summarized in Table 2. The results showed that the PBI-DIm-Si hybrid membrane retained $79.6 \%$ of its elastic modulus of the dry state (from $0.64 \mathrm{GPa}$ to $0.51 \mathrm{GPa}$ ) when it reached a fully hydrated state. In contrast, the loss of elastic modulus was up to $71.4 \%$ (from $0.63 \mathrm{GPa}$ to $0.18 \mathrm{GPa}$ ) for the PBI-DIm membrane. It is worth noting that both the tensile strength and elongation at break of the PBI-DIm-Si hybrid membrane in the fully hydrated state (28.2 MPa and $27.2 \%)$ were even higher than those of the PBI-DIm membrane in the dry state (26.0 MPa and 15.2\%). This result revealed that the organic-inorganic hybrid network effectively enhanced the mechanical property of the AEM based on side chain type quaternized PBI. Additionally, the tensile strength values of these two membranes in the fully hydrated state were comparable with the reported value of Nafion 112 (19.1 MPa) [67] and other quaternized PBI membranes [24,68,69], suggesting that they were mechanically strong enough for fuel cell applications.

Furthermore, it is worth noting that all the tensile properties in terms of elastic modulus, tensile strength did not differ significantly before and after the alkaline treatment in $2 \mathrm{M} \mathrm{KOH}$ solution at $80^{\circ} \mathrm{C}$ for $120 \mathrm{~h}$, whether for the PBI-DIm or PBI-DIm-Si hybrid membranes in the dry state (Table 2). This result confirmed that the PBI polymer backbone was alkaline stable, as mentioned earlier. 
Table 2. Mechanical properties of the PBI-DIm and PBI-DIm-Si hybrid membranes.

\begin{tabular}{|c|c|c|c|c|}
\hline State & AEM & $\begin{array}{c}\text { Elastic Modulus } \\
\text { (GPa) }\end{array}$ & $\begin{array}{l}\text { Tensile Strength } \\
\text { (MPa) }\end{array}$ & $\begin{array}{c}\text { Elongation at Break } \\
(\%)\end{array}$ \\
\hline \multirow{2}{*}{ Dry } & PBI-DIm & $0.63 \pm 0.14$ & $26.0 \pm 3.5$ & $15.2 \pm 3.6$ \\
\hline & PBI-Dim-Si hybrid & $0.64 \pm 0.11$ & $32.9 \pm 3.7$ & $16.9 \pm 4.2$ \\
\hline \multirow{2}{*}{ Fully hydrated } & PBI-DIm & $0.18 \pm 0.04$ & $17.0 \pm 0.7$ & $31.9 \pm 4.0$ \\
\hline & PBI-Dim-Si hybrid & $0.51 \pm 0.04$ & $28.2 \pm 2.5$ & $27.2 \pm 4.83$ \\
\hline \multirow{2}{*}{ Dry, alkaline degraded ${ }^{1}$} & PBI-DIm & $0.64 \pm 0.12$ & $25.8 \pm 3.8$ & $15.9 \pm 3.5$ \\
\hline & PBI-Dim-Si hybrid & $0.66 \pm 0.09$ & $33.1 \pm 4.1$ & $18.3 \pm 4.5$ \\
\hline
\end{tabular}

${ }^{1}$ The membrane samples were immersed in $2 \mathrm{M} \mathrm{KOH}$ at $80^{\circ} \mathrm{C}$ for $120 \mathrm{~h}$ before drying and subsequently tensile testing.

To evaluate the oxidative stability of the PBI-DIm and PBI-DIm-Si hybrid membranes, they were immersed in an aqueous solution containing Fenton agents $\left(3 \mathrm{wt} . \% \mathrm{H}_{2} \mathrm{O}_{2}\right.$ and $4 \mathrm{ppm} \mathrm{Fe}^{2+}$ ) full of radicals at $80^{\circ} \mathrm{C}$ for a period of time. Figure 7 shows the remaining weight of the membrane sample as a function of time during the Fenton test. It was found that the remaining weight of the BI-DIm-Si hybrid membrane was $90.7 \mathrm{wt} . \%$ after $6 \mathrm{~h}$, which was much higher than that of the PBI-DIm membrane (64.9 wt.\%). This result indicated that the organic-inorganic hybrid allowed the quaternized PBI to improve the resistance to the radical attack and reduce chemical degradation efficiently.

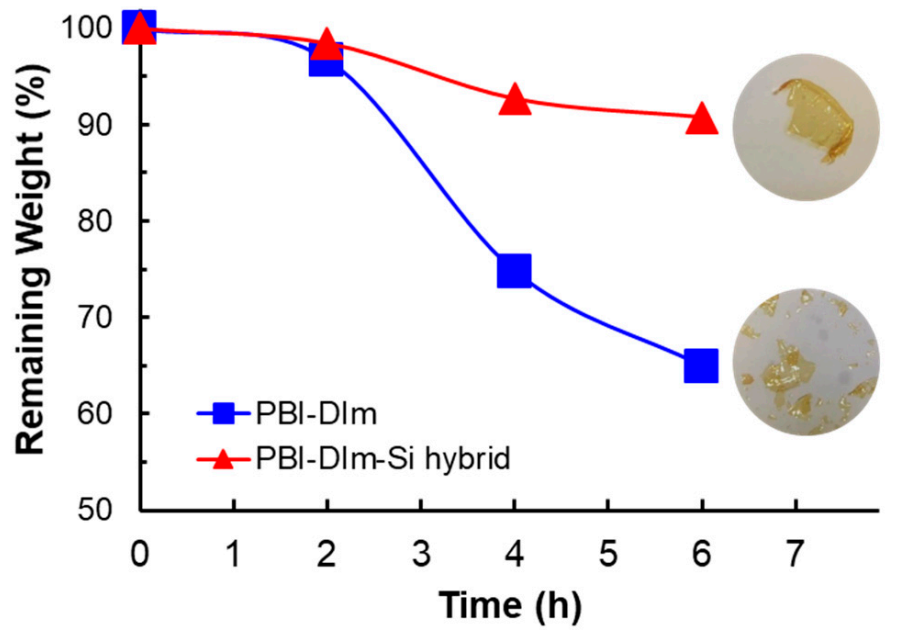

Figure 7. Oxidative stability of the PBI-DIm and PBI-DIm-Si hybrid membranes.

\subsection{Fuel Cell Performance}

In order to confirm the applicability of the PBI-DIm and PBI-DIm-Si hybrid membranes in AEMFCs, the fuel cell performance of their MEAs was examined and further compared with that of the commercially available AEM Sistainion X37-RT. Figure 8 shows the polarization curves of the MEAs conducted under humidified hydrogen $\left(50 \mathrm{~mL} \mathrm{~min}^{-1}\right)$ and oxygen $\left(100 \mathrm{~mL} \mathrm{~min}^{-1}\right)$ atmosphere at $60^{\circ} \mathrm{C}$ without back-pressure. The open-circuit voltages (OCVs) of fuel cells for these AEMs were detected in the range of $1.01 \mathrm{~V}$ and $1.03 \mathrm{~V}$, indicating that the gas crossover problem was insignificant. The maximum power density of the PBI-DIm membrane reached up to $241 \mathrm{~mW} \mathrm{~cm}^{-2}$, which was higher than that of Sistainion X37-RT $\left(147 \mathrm{~mW} \mathrm{~cm}^{-2}\right)$ as well as the reported values of other commercially available AEMs Fumatech FAA-3 $\left(223 \mathrm{~mW} \mathrm{~cm}^{-2}\right)$ and Tokuyama AHA $\left(40.2 \mathrm{~mW} \mathrm{~cm}^{-2}\right)$ [70,71]. The fuel cell performance of the MEA based on the PBI-DIm-Si hybrid membrane was found to be not as good as that of the PBI-DIm membrane, which would result from its relatively lower hydroxide conductivity $\left(1.32 \times 10^{-2} \mathrm{~S} \mathrm{~cm}^{-1}\right.$ at $\left.60^{\circ} \mathrm{C}\right)$. Despite that, it achieved the maximum power density of $152 \mathrm{~mW} \mathrm{~cm}^{-2}$, which was comparable to the performance of the MEA based on Sistainion X37-RT. These results suggested that both the 
pristine and organic-inorganic hybrid membranes of dimethylimidazolium-functionalized PBI are promising for fuel cell applications.

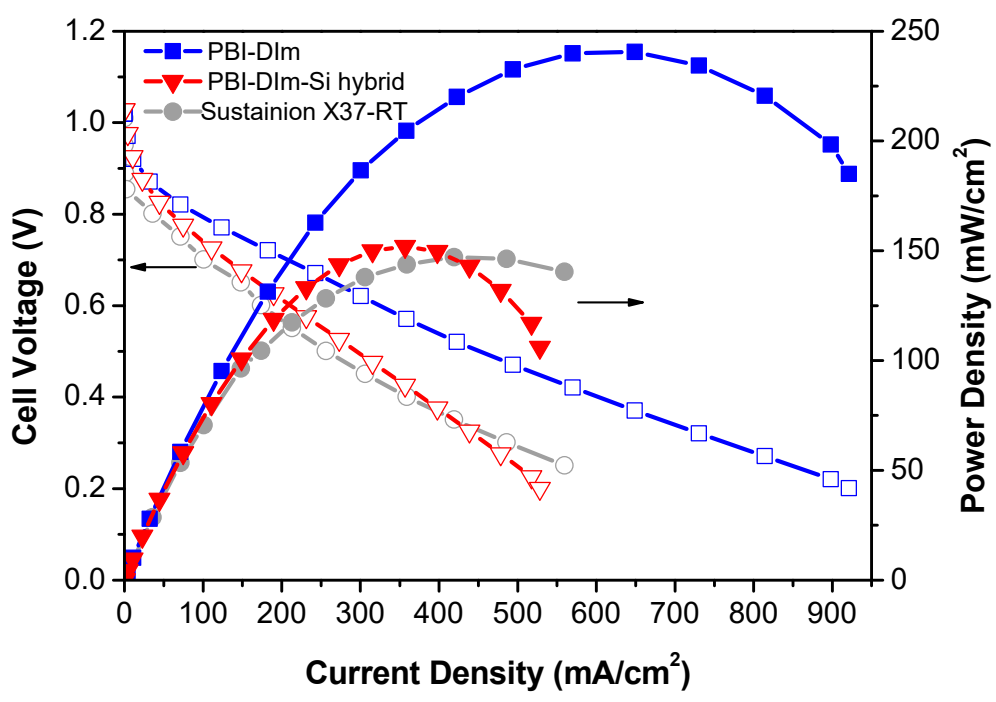

Figure 8. Fuel cell performance for the MEA based on the PBI-DIm, PBI-DIm-Si hybrid, and commercially available AEM Sistainion X37-RT.

\section{Conclusions}

In this work, the silane-induced crosslinking of the side chain type BPI was studied. The pristine and organic-inorganic hybrid membranes of quaternized PBIs with side chains containing dimethylimidazolium groups were successfully prepared and characterized. The experimental results confirmed that the silane-induced crosslinking networks can improve thermal stability, dimensional stability, mechanical strength, and oxidative stability of the AEMs based on dimethylimidazolium-functionalized PBI. The PBI-DIm pristine membrane successfully developed a membrane morphology of distinguishable hydrophilic/hydrophobic phase separation. However, the phase separation was no longer clear when many silica-based domains appeared in the PBI-DIm-Si hybrid membrane, evidenced by AFM phase image mapping, SAXS diffraction, and XPS spectra deconvolution. Both membranes exhibited sufficient hydroxide conductivity $\left(>10^{-2} \mathrm{~S} \mathrm{~cm}^{-1}\right)$ and good alkaline stability in $2 \mathrm{M} \mathrm{KOH}$ at $80^{\circ} \mathrm{C}$. Meanwhile, the power densities of the MEAs based on these two membranes were higher than that of commercially available AEM Sistainion X37-RT (147 $\left.\mathrm{mW} \mathrm{cm}^{-2}\right)$, demonstrating the promising potential of these two AEMs used in AEMFCs. Their long-term durability of fuel cell performance is worthy of evaluation in future work.

Author Contributions: Conceptualization, L.-C.J.; methodology, L.-C.J. and C.-W.C.; investigation, C.-W.C., C.-Y.H. and B.-Y.L.; resources, K.-S.H.; data curation, L.-C.J., C.-W.C. and K.-S.H.; writingoriginal draft preparation, L.-C.J. and C.-W.C.; writing—review and editing, S.L.-C.H. and T.-H.H.; supervision, S.L.-C.H. and T.-H.H.; funding acquisition, L.-C.J. and S.L.-C.H. All authors have read and agreed to the published version of the manuscript.

Funding: This research was funded by Ministry of Science and Technology, Taiwan, grant number MOST 108-2218-E-992-306-MY2 and 108-2221-E-006-119.

Institutional Review Board Statement: Not applicable.

Informed Consent Statement: Not applicable.

Acknowledgments: The authors acknowledge the use of XPS (ESCA, ULVAC PHI5000 VersaProbe) and HR-SEM (ITACHI SU8000) belonging to the Instrument Center of National Cheng Kung University along with the operation service from J.C. Li and H.J. Shih.

Conflicts of Interest: The authors declare no conflict of interest. 


\section{References}

1. Barbir, F.; Gómez, T. Efficiency and economics of proton exchange membrane (PEM) fuel cells. Int. J. Hydrog. Energy 1997, 22, 1027-1037. [CrossRef]

2. Zhang, H.; Shen, P.K. Recent Development of Polymer Electrolyte Membranes for Fuel Cells. Chem. Rev. 2012, 112, $2780-2832$. [CrossRef] [PubMed]

3. Liang, M.; Liu, Y.; Xiao, B.; Yang, S.; Wang, Z.; Han, H. An analytical model for the transverse permeability of gas diffusion layer with electrical double layer effects in proton exchange membrane fuel cells. Int. J. Hydrog. Energy 2018, 43, 17880-17888. [CrossRef]

4. Liang, M.; Fu, C.; Xiao, B.; Luo, L.; Wang, Z. A fractal study for the effective electrolyte diffusion through charged porous media. Int. J. Heat Mass Transf. 2019, 137, 365-371. [CrossRef]

5. Shin, D.W.; Guiver, M.D.; Lee, Y.M. Hydrocarbon-Based Polymer Electrolyte Membranes: Importance of Morphology on Ion Transport and Membrane Stability. Chem. Rev. 2017, 117, 4759-4805. [CrossRef]

6. Gutru, R.; Turtayeva, Z.; Xu, F.; Maranzana, G.; Vigolo, B.; Desforges, A. A comprehensive review on water management strategies and developments in anion exchange membrane fuel cells. Int. J. Hydrog. Energy 2020, 45, 19642-19663. [CrossRef]

7. Cheng, J.; He, G.; Zhang, F. A mini-review on anion exchange membranes for fuel cell applications: Stability issue and addressing strategies. Int. J. Hydrog. Energy 2015, 40, 7348-7360. [CrossRef]

8. An, L.; Zhao, T.S.; Shen, S.Y.; Wu, Q.X.; Chen, R. Alkaline direct oxidation fuel cell with non-platinum catalysts capable of converting glucose to electricity at high power output. J. Power Sources 2011, 196, 186-190. [CrossRef]

9. Firouzjaie, H.A.; Mustain, W.E. Catalytic Advantages, Challenges, and Priorities in Alkaline Membrane Fuel Cells. ACS Catal. 2020, 10, 225-234. [CrossRef]

10. Maurya, S.; Shin, S.-H.; Kim, Y.; Moon, S.-H. A review on recent developments of anion exchange membranes for fuel cells and redox flow batteries. RSC Adv. 2015, 5, 37206-37230. [CrossRef]

11. Danks, T.N.; Slade, R.C.T.; Varcoe, J.R. Comparison of PVDF- and FEP-based radiation-grafted alkaline anion-exchange membranes for use in low temperature portable DMFCs. J. Mater. Chem. 2002, 12, 3371-3373. [CrossRef]

12. Pan, Z.F.; An, L.; Zhao, T.S.; Tang, Z.K. Advances and challenges in alkaline anion exchange membrane fuel cells. Prog. Energy Combust. Sci. 2018, 66, 141-175. [CrossRef]

13. Xu, F.; Su, Y.; Lin, B. Progress of Alkaline Anion Exchange Membranes for Fuel Cells: The Effects of Micro-Phase Separation. Front. Mater. 2020, 7, 4. [CrossRef]

14. Varcoe, J.R.; Atanassov, P.; Dekel, D.R.; Herring, A.M.; Hickner, M.A.; Kohl, P.A.; Kucernak, A.R.; Mustain, W.E.; Nijmeijer, K.; Scott, K.; et al. Anion-exchange membranes in electrochemical energy systems. Energy Environ. Sci. 2014, 7, 3135-3191. [CrossRef]

15. Zhou, T.; Shao, R.; Chen, S.; He, X.; Qiao, J.; Zhang, J. A review of radiation-grafted polymer electrolyte membranes for alkaline polymer electrolyte membrane fuel cells. J. Power Sources 2015, 293, 946-975. [CrossRef]

16. Gottesfeld, S.; Dekel, D.R.; Page, M.; Bae, C.; Yan, Y.; Zelenay, P.; Kim, Y.S. Anion exchange membrane fuel cells: Current status and remaining challenges. J. Power Sources 2018, 375, 170-184. [CrossRef]

17. Hickner, M.A. Strategies for Developing New Anion Exchange Membranes and Electrode Ionomers. Electrochem. Soc. Interface 2017, 26, 69-73. [CrossRef]

18. He, Y.; Pan, J.; Wu, L.; Zhu, Y.; Ge, X.; Ran, J.; Yang, Z.; Xu, T. A Novel Methodology to Synthesize Highly Conductive Anion Exchange Membranes. Sci. Rep. 2015, 5, 13417. [CrossRef]

19. Lin, C.X.; Zhuo, Y.Z.; Lai, A.N.; Zhang, Q.G.; Zhu, A.M.; Ye, M.L.; Liu, Q.L. Side-chain-type anion exchange membranes bearing pendent imidazolium-functionalized poly(phenylene oxide) for fuel cells. J. Membr. Sci. 2016, 513, 206-216. [CrossRef]

20. Wei, H.; Li, Y.; Wang, S.; Tao, G.; Wang, T.; Cheng, S.; Yang, S.; Ding, Y. Side-chain-type imidazolium-functionalized anion exchange membranes: The effects of additional hydrophobic side chains and their hydrophobicity. J. Membr. Sci. 2019, 579, 219-229. [CrossRef]

21. Guo, D.; Lai, A.N.; Lin, C.X.; Zhang, Q.G.; Zhu, A.M.; Liu, Q.L. Imidazolium-Functionalized Poly(arylene ether sulfone) AnionExchange Membranes Densely Grafted with Flexible Side Chains for Fuel Cells. ACS Appl. Mater. Interfaces 2016, 8, $25279-25288$. [CrossRef]

22. Swaby, S.; Ureña, N.; Pérez-Prior, M.T.; Várez, A.; Levenfeld, B. Synthesis and Characterization of Novel Anion Exchange Membranes Based on Semi-Interpenetrating Networks of Functionalized Polysulfone: Effect of Ionic Crosslinking. Polymers 2021, 13, 958. [CrossRef] [PubMed]

23. Li, Z.; Jiang, Z.; Tian, H.; Wang, S.; Zhang, B.; Cao, Y.; He, G.; Li, Z.; Wu, H. Preparing alkaline anion exchange membrane with enhanced hydroxide conductivity via blending imidazolium-functionalized and sulfonated poly(ether ether ketone). J. Power Sources 2015, 288, 384-392. [CrossRef]

24. Lin, B.; Xu, F.; Su, Y.; Han, J.; Zhu, Z.; Chu, F.; Ren, Y.; Zhu, L.; Ding, J. Ether-Free Polybenzimidazole Bearing Pendant Imidazolium Groups for Alkaline Anion Exchange Membrane Fuel Cells Application. ACS Appl. Energy Mater. 2020, 3, 1089-1098. [CrossRef]

25. Wang, X.; Chen, W.; Yan, X.; Li, T.; Wu, X.; Zhang, Y.; Zhang, F.; Pang, B.; He, G. Pre-removal of polybenzimidazole anion to improve flexibility of grafted quaternized side chains for high performance anion exchange membranes. J. Power Sources 2020, 451, 227813. [CrossRef] 
26. Wang, X.; Chen, W.; Li, T.; Yan, X.; Zhang, Y.; Zhang, F.; Wu, X.; Pang, B.; Li, J.; He, G. Ultra-thin quaternized polybenzimidazole anion exchange membranes with throughout $\mathrm{OH}-$ conducive highway networks for high-performance fuel cells. J. Mater. Chem. A 2021, 9, 7522-7530. [CrossRef]

27. He, X.; Cheng, C.; Huang, S.; Zhang, F.; Duan, Y.; Zhu, C.; Guo, Y.; Wang, K.; Chen, D. Alkaline anion exchange membranes with imidazolium-terminated flexible side-chain cross-linked topological structure based on ROMP-type norbornene copolymers. Polymer 2020, 195, 122412. [CrossRef]

28. Wang, C.; Mo, B.; He, Z.; Shao, Q.; Pan, D.; Wujick, E.; Guo, J.; Xie, X.; Xie, X.; Guo, Z. Crosslinked norbornene copolymer anion exchange membrane for fuel cells. J. Membr. Sci. 2018, 556, 118-125. [CrossRef]

29. Mohanty, A.D.; Ryu, C.Y.; Kim, Y.S.; Bae, C. Stable Elastomeric Anion Exchange Membranes Based on Quaternary AmmoniumTethered Polystyrene-b-poly(ethylene-co-butylene)-b-polystyrene Triblock Copolymers. Macromolecules 2015, 48, 7085-7095. [CrossRef]

30. Park, H.-S.; Hong, C.-K. Anion Exchange Membrane Based on Sulfonated Poly (Styrene-Ethylene-Butylene-Styrene) Copolymers. Polymers 2021, 13, 1669. [CrossRef]

31. Mohanty, A.D.; Tignor, S.E.; Krause, J.A.; Choe, Y.-K.; Bae, C. Systematic Alkaline Stability Study of Polymer Backbones for Anion Exchange Membrane Applications. Macromolecules 2016, 49, 3361-3372. [CrossRef]

32. Hou, H.; Wang, S.; Jiang, Q.; Jin, W.; Jiang, L.; Sun, G. Durability study of KOH doped polybenzimidazole membrane for air-breathing alkaline direct ethanol fuel cell. J. Power Sources 2011, 196, 3244-3248. [CrossRef]

33. Aili, D.; Hansen, M.K.; Renzaho, R.F.; Li, Q.; Christensen, E.; Jensen, J.O.; Bjerrum, N.J. Heterogeneous anion conducting membranes based on linear and crosslinked $\mathrm{KOH}$ doped polybenzimidazole for alkaline water electrolysis. J. Membr. Sci. 2013, 447, 424-432. [CrossRef]

34. Wu, Q.X.; Pan, Z.F.; An, L. Recent advances in alkali-doped polybenzimidazole membranes for fuel cell applications. Renew. Sustain. Energy Rev. 2018, 89, 168-183. [CrossRef]

35. Qu, C.; Zhang, H.; Zhang, F.; Liu, B. A high-performance anion exchange membrane based on bi-guanidinium bridged polysilsesquioxane for alkaline fuel cell application. J. Mater. Chem. 2012, 22, 8203-8207. [CrossRef]

36. He, X.; Han, Z.; Yang, Y.; Wang, S.; Tu, G.; Huang, S.; Zhang, F.; Chen, D. The preparation and application of a ROMP-type epoxy-functionalized norbornene copolymer and its hybrid alkaline anion exchange membranes. RSC Adv. 2017, 7, 55977-55985. [CrossRef]

37. Li, X.; Cheng, J.; Liu, Y.; Gong, S.; He, G.; Li, L.; Li, S.; Zhang, F. Improved conductivity and stability of anion exchange membrane modified with bi-phenylguanidinium bridged silsesquioxane. Int. J. Hydrog. Energy 2017, 42, 21016-21026. [CrossRef]

38. He, X.; Jiang, X.; Wang, Z.; Deng, Y.; Han, Z.; Yang, Y.; Chen, D. Crosslinked hydroxyl-conductive copolymer/silica composite membranes based on addition-type polynorbornene for alkaline anion exchange membrane fuel cell applications. Polym. Eng. Sci. 2018, 58, 13-21. [CrossRef]

39. Wang, Y.; Wang, D.; Wang, J.; Wang, L. Preparation and characterization of a sol-gel derived silica/PVA-Py hybrid anion exchange membranes for alkaline fuel cell application. J. Electroanal. Chem. 2020, 873, 114342. [CrossRef]

40. Jheng, L.C.; Hsu, S.L.C.; Lin, B.Y.; Hsu, Y.L. Quaternized polybenzimidazoles with imidazolium cation moieties for anion exchange membrane fuel cells. J. Membr. Sci. 2014, 460, 160-170. [CrossRef]

41. Lin, X.; Varcoe, J.R.; Poynton, S.D.; Liang, X.; Ong, A.L.; Ran, J.; Li, Y.; Xu, T. Alkaline polymer electrolytes containing pendant dimethylimidazolium groups for alkaline membrane fuel cells. J. Mater. Chem. A 2013, 1, 7262-7269. [CrossRef]

42. Sun, Z.; Pan, J.; Guo, J.; Yan, F. The Alkaline Stability of Anion Exchange Membrane for Fuel Cell Applications: The Effects of Alkaline Media. Adv. Sci. 2018, 5, 1800065. [CrossRef] [PubMed]

43. Chuang, S.-W.; Hsu, S.L.-C. Synthesis and properties of a new fluorine-containing polybenzimidazole for high-temperature fuel-cell applications. J. Polym. Sci. Part. A Polym. Chem. 2006, 44, 4508-4513. [CrossRef]

44. Jheng, L.-C.; Rosidah, A.A.; Hsu, S.L.-C.; Ho, K.-S.; Pan, C.-J.; Cheng, C.-W. Nanocomposite membranes of polybenzimidazole and amine-functionalized carbon nanofibers for high temperature proton exchange membrane fuel cells. RSC Adv. 2021, 11, 9964-9976. [CrossRef]

45. Dai, J.; He, G.; Ruan, X.; Zheng, W.; Pan, Y.; Yan, X. Constructing a rigid crosslinked structure for enhanced conductivity of imidazolium functionalized polysulfone hydroxide exchange membrane. Int. J. Hydrog. Energy 2016, 41, 10923-10934. [CrossRef]

46. Chen, J.; Shen, C.; Gao, S.; Yuan, Y.; Ren, X. Novel imidazole-grafted hybrid anion exchange membranes based on poly (2,6-dimethyl-1,4-phenylene oxide) for fuel cell applications. J. Appl. Polym. Sci. 2018, 135, 46034. [CrossRef]

47. Jheng, L.-C.; Tai, C.-K.; Hsu, S.L.-C.; Lin, B.-Y.; Chen, L.; Wang, B.-C.; Chiang, L.-K.; Ko, W.-C. Study on the alkaline stability of imidazolium and benzimidazolium based polyelectrolytes for anion exchange membrane fuel cells. Int. J. Hydrog. Energy 2017, 42, 5315-5326. [CrossRef]

48. Ngo, H.L.; Lecompte, K.; Hargens, L.; McEwen, A.B. Thermal properties of imidazolium ionic liquids. Thermochim. Acta 2000, 357, 97-102. [CrossRef]

49. Khan, S.; Lorenzelli, L.; Dahiya, R.S. Technologies for Printing Sensors and Electronics Over Large Flexible Substrates: A Review. IEEE Sens. J. 2015, 15, 3164-3185. [CrossRef]

50. Kim, A.R.; Vinothkannan, M.; Song, M.H.; Lee, J.-Y.; Lee, H.-K.; Yoo, D.J. Amine functionalized carbon nanotube (ACNT) filled in sulfonated poly(ether ether ketone) membrane: Effects of ACNT in improving polymer electrolyte fuel cell performance under reduced relative humidity. Compos. Part. B Eng. 2020, 188, 107890. [CrossRef] 
51. Dietrich, P.M.; Streeck, C.; Glamsch, S.; Ehlert, C.; Lippitz, A.; Nutsch, A.; Kulak, N.; Beckhoff, B.; Unger, W.E.S. Quantification of Silane Molecules on Oxidized Silicon: Are there Options for a Traceable and Absolute Determination? Anal. Chem. 2015, 87, 10117-10124. [CrossRef]

52. Hossain, M.A.; Jang, H.; Lee, S.; Hong, T.; Jin, L.; Tan, F.; Kim, D.; Kim, W. Comparison of properties of anion conductive Parmax membranes containing imidazolium cation and quaternary ammonium. Int. J. Hydrog. Energy 2015, 40, 1324-1332. [CrossRef]

53. Feng, T.; Lin, B.; Zhang, S.; Yuan, N.; Chu, F.; Hickner, M.A.; Wang, C.; Zhu, L.; Ding, J. Imidazolium-based organic-inorganic hybrid anion exchange membranes for fuel cell applications. J. Membr. Sci. 2016, 508, 7-14. [CrossRef]

54. Feng, C.; He, P.F. Moisture and thermal expansion properties and mechanism of interaction between ions of a Nafion-based membrane electrode assembly. RSC Adv. 2017, 7, 34556-34566. [CrossRef]

55. Wang, Y.; Qiao, X.; Liu, M.; Liu, L.; Li, N. The effect of $-\mathrm{NH}-$ on quaternized polybenzimidazole anion exchange membranes for alkaline fuel cells. J. Membr. Sci. 2021, 626, 119178. [CrossRef]

56. Li, N.; Zhang, Q.; Wang, C.; Lee, Y.M.; Guiver, M.D. Phenyltrimethylammonium Functionalized Polysulfone Anion Exchange Membranes. Macromolecules 2012, 45, 2411-2419. [CrossRef]

57. Chen, C.; Tse, Y.-L.S.; Lindberg, G.E.; Knight, C.; Voth, G.A. Hydroxide Solvation and Transport in Anion Exchange Membranes. J. Am. Chem. Soc. 2016, 138, 991-1000. [CrossRef] [PubMed]

58. Kim, S.H.; Lee, K.H.; Chu, J.Y.; Kim, A.R.; Yoo, D.J. Enhanced Hydroxide Conductivity and Dimensional Stability with Blended Membranes Containing Hyperbranched PAES/Linear PPO as Anion Exchange Membranes. Polymers 2020, 12, 3011. [CrossRef] [PubMed]

59. Lee, K.H.; Chu, J.Y.; Kim, A.R.; Yoo, D.J. Fabrication of High-Alkaline Stable Quaternized Poly(arylene ether ketone)/Graphene Oxide Derivative Including Zwitterion for Alkaline Fuel Cells. ACS Sustain. Chem. Eng. 2021, 9, 8824-8834. [CrossRef]

60. Chu, J.Y.; Lee, K.H.; Kim, A.R.; Yoo, D.J. Graphene-mediated organic-inorganic composites with improved hydroxide conductivity and outstanding alkaline stability for anion exchange membranes. Compos. Part. B Eng. 2019, 164, 324-332. [CrossRef]

61. Yoshimura, K.; Hiroki, A.; Yu, H.-C.; Zhao, Y.; Shishitani, H.; Yamaguchi, S.; Tanaka, H.; Maekawa, Y. Alkaline durable 2methylimidazolium containing anion-conducting electrolyte membranes synthesized by radiation-induced grafting for direct hydrazine hydrate fuel cells. J. Membr. Sci. 2019, 573, 403-410. [CrossRef]

62. Dekel, D.R.; Amar, M.; Willdorf, S.; Kosa, M.; Dhara, S.; Diesendruck, C.E. Effect of Water on the Stability of Quaternary Ammonium Groups for Anion Exchange Membrane Fuel Cell Applications. Chem. Mater. 2017, 29, 4425-4431. [CrossRef]

63. Adhikari, S.; Pagels, M.K.; Jeon, J.Y.; Bae, C. Ionomers for electrochemical energy conversion \& storage technologies. Polymer 2020, 211, 123080.

64. Hübner, G.; Roduner, E. EPR investigation of HO/ radical initiated degradation reactions of sulfonated aromatics as model compounds for fuel cell proton conducting membranes. J. Mater. Chem. 1999, 9, 409-418. [CrossRef]

65. Zhu, L.; Zimudzi, T.J.; Wang, Y.; Yu, X.; Pan, J.; Han, J.; Kushner, D.I.; Zhuang, L.; Hickner, M.A. Mechanically Robust Anion Exchange Membranes via Long Hydrophilic Cross-Linkers. Macromolecules 2017, 50, 2329-2337. [CrossRef]

66. Wang, X.; Wang, P.; Sun, Y.; Wang, J.; Fang, H.; Yang, S.; Wei, H.; Ding, Y. A mechanically strong and tough anion exchange membrane engineered with non-covalent modalities. Chem. Commun. 2017, 53, 12369-12372. [CrossRef]

67. Liu, F.; Yi, B.; Xing, D.; Yu, J.; Zhang, H. Nafion/PTFE composite membranes for fuel cell applications. J. Membr. Sci. 2003, 212, 213-223. [CrossRef]

68. Changkhamchom, S.; Kunanupatham, P.; Phasuksom, K.; Sirivat, A. Anion exchange membranes composed of quaternized polybenzimidazole and quaternized graphene oxide for glucose fuel cell. Int. J. Hydrog. Energy 2021, 46, 5642-5652. [CrossRef]

69. Abdi, Z.G.; Chiu, T.-H.; Pan, Y.-Z.; Chen, J.-C. Anion exchange membranes based on ionic polybenzimidazoles crosslinked by thiol-ene reaction. React. Funct. Polym. 2020, 156, 104719. [CrossRef]

70. Carmo, M.; Doubek, G.; Sekol, R.C.; Linardi, M.; Taylor, A.D. Development and electrochemical studies of membrane electrode assemblies for polymer electrolyte alkaline fuel cells using FAA membrane and ionomer. J. Power Sources 2013, 230, 169-175. [CrossRef]

71. Lin, C.; Wang, J.; Shen, G.; Duan, J.; Xie, D.; Cheng, F.; Zhang, Y.; Zhang, S. Construction of crosslinked polybenz imidazole-based anion exchange membranes with ether-bond-free backbone. J. Membr. Sci. 2019, 590, 117303. [CrossRef] 